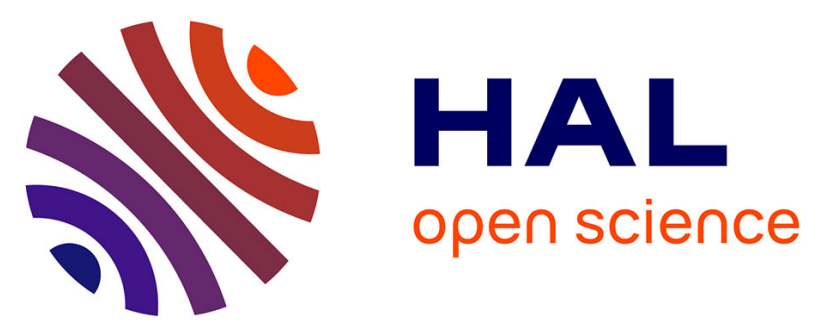

\title{
A novel dual inhibitor of calpains and lipid peroxidation (BN82270) rescues the cochlea from sound trauma.
}

Jing Wang, Bernadette Pignol, Pierre-Etienne Chabrier, Takaomi Saido, Ruth Lloyd, Yong Tang, Marc Lenoir, Jean-Luc Puel

\section{- To cite this version:}

Jing Wang, Bernadette Pignol, Pierre-Etienne Chabrier, Takaomi Saido, Ruth Lloyd, et al.. A novel dual inhibitor of calpains and lipid peroxidation (BN82270) rescues the cochlea from sound trauma.. Neuropharmacology, 2007, 52 (6), pp.1426-37. 10.1016/j.neuropharm.2007.02.007 . inserm-00145385

\section{HAL Id: inserm-00145385 https://www.hal.inserm.fr/inserm-00145385}

Submitted on 11 May 2007

HAL is a multi-disciplinary open access archive for the deposit and dissemination of scientific research documents, whether they are published or not. The documents may come from teaching and research institutions in France or abroad, or from public or private research centers.
L'archive ouverte pluridisciplinaire HAL, est destinée au dépôt et à la diffusion de documents scientifiques de niveau recherche, publiés ou non, émanant des établissements d'enseignement et de recherche français ou étrangers, des laboratoires publics ou privés. 


\section{HAL author manuscript}

Elsevier Editorial System(tm) for Neuropharmacology

Manuscript Draft

Manuscript Number: NEUROPHARM-D-06-00211R2

Title: A novel dual inhibitor of calpains and lipid peroxidation (BN82270) rescues the cochlea from sound trauma

Article Type: Research Paper

Section/Category:

Keywords: sound trauma, necrosis, apoptosis, calpains, inhibitor, free radical, organ of Corti

Corresponding Author: Pr. Jean-Luc Puel,

Corresponding Author's Institution: INSERM

First Author: jing wang, PhD MD

Order of Authors: jing wang, PhD MD; Bernadette Pignol, PhD; Pierre-Etienne Chabrier, PhD; Takaomi Saido, PhD; Ruth ILloyd, M.D.; Yong Tang, MD; Marc Lenoir, PhD; Jean-Luc Puel

Manuscript Region of Origin: 
Free radical and calcium buffering mechanisms are implicated in cochlear cell damage that has been induced by sound trauma. Thus in this study we evaluated the therapeutic effect of a novel dual inhibitor of calpains and of lipid peroxidation (BN 82270) on the permanent hearing and hair cell loss induced by sound trauma. Perfusion of BN 82270 into the scala tympani of the guinea pig cochlea prevented the formation of calpain-cleaved fodrin, translocation of cytochrome c, DNA fragmentation and hair cell degeneration caused by sound trauma. This was confirmed by functional tests in vivo, showing a clear dose-dependent reduction of permanent hearing loss $\left(\mathrm{ED}_{50}=4.07 \mu \mathrm{M}\right)$ with almost complete protection at $100 \mu \mathrm{M}$. Furthermore, BN82270 still remained effective even when applied onto the round window membrane after sound trauma had occurred, within a therapeutic window of 24 hours. This indicates that BN 82270 may be of potential therapeutic value in treating the cochlea after sound trauma. 
A novel dual inhibitor of calpains and lipid peroxidation (BN82270) rescues the cochlea from sound trauma

Jing Wang ${ }^{a}$, Bernadette Pignol ${ }^{b}$, Pierre-Etienne Chabrier $^{b}$, Takaomi Saido $^{c}$, Ruth Lloyd $^{a}$, Yong Tang, ${ }^{a}$ Marc Lenoir ${ }^{a}$, and Jean-Luc Puel ${ }^{* a}$

a INSERM - UMR 583 and Université de Montpellier 1: Physiopathologie et thérapie des déficits sensoriels et moteurs, 80, rue Augustin Fliche, 34295 Montpellier, France..

${ }^{b}$ Ipsen Research Laboratories, Institut Henri Beaufour, 5, Avenue du Canada, 91966 Les Ulis Cedex, France.

${ }^{c}$ Laboratory for Proteolytic Neuroscience, Institute of Physical and Chemical Research, RIKEN Brain Science Institute, 2-1 Hirosawa, Saitama 350-0198, Japan

Running title: BN82270 rescues the cochlea from trauma

Corresponding author: Jean-Luc PUEL, INSERM - UMR 583 and Université de Montpellier 1: Physiopathologie et thérapie des déficits sensoriels et moteurs, 80 , rue Augustin Fliche, 34295 Montpellier, France, Tel: (33) 499636 009, Fax: (33) 499636 020, Email : puel@montp.inserm.fr 


\section{ABSTRACT}

Free radical and calcium buffering mechanisms are implicated in cochlear cell damage that has been induced by sound trauma. Thus in this study we evaluated the therapeutic effect of a novel dual inhibitor of calpains and of lipid peroxidation (BN 82270) on the permanent hearing and hair cell loss induced by sound trauma. Perfusion of BN 82270 into the scala tympani of the guinea pig cochlea prevented the formation of calpain-cleaved fodrin, translocation of cytochrome c, DNA fragmentation and hair cell degeneration caused by sound trauma. This was confirmed by functional tests in vivo, showing a clear dose-dependent reduction of permanent hearing loss $\left(\mathrm{ED}_{50}=4.07 \mu \mathrm{M}\right)$ with almost complete protection at $100 \mu \mathrm{M}$. Furthermore, BN82270 still remained effective even when applied onto the round window membrane after sound trauma had occurred, within a therapeutic window of 24 hours. This indicates that BN 82270 may be of potential therapeutic value in treating the cochlea after sound trauma.

Key words: sound trauma, necrosis, apoptosis, calpains, inhibitor, free radical, organ of Corti 


\section{INTRODUCTION}

Hearing deficits induced by exposure to intense sound have been extensively documented. They are primarily due to the loss of hair cells leading to degeneration of auditory neurons (Nordmann et al., 2000). Apoptosis, also known as programmed cell death, involves chromatin and cytoplasmic condensation, progressive contraction of cell volume, and preservation of the integrity of membrane-bound particles (Allen et al., 1997; Wyllie and Kerr 1980). Necrosis is generally characterized by early swelling of the cytoplasm and disintegration of cellular structures, which ultimately culminate in cell lysis and subsequent release of cellular debris into the extracellular space (Searle et al., 1982; Dive et al., 1992). Although both apoptotic and necrotic processes seem to be involved in noise-induced cochlear cell death, characteristic features of the damaged cell nuclei attest that apoptosis is the primary and the predominant mode of hair cell death following noise trauma (Hu et al., 2000; Nicotera et al., 2003). However, the detailed mechanism of noise-induced apoptotic sensory cell death pathway is still under investigation.

Experimental observations support the importance of reactive oxygen species in noise-induced hearing loss (for reviews, see Henderson et al., 1999; Kopke et al., 1999; Le Prell et al., 2003). Noise exposure increased levels of 8-isoprostane in the organ of Corti (Ohinata et al., 2000), hydroxyl radicals in cochlear fluids (Ohlemiller et al., 1999) and superoxide anion radicals in the stria vascularis (Yamane et al., 1995; Yamasoba et al., 1998). Reactive oxygen species (ROS) and lipid peroxidation play an important role in noise- and ototoxic-induced hearing loss (Henderson et al., 2006; So et 
al., 2005). Increased levels of reactive oxygen species (ROS) can also trigger the cochlear cell death signaling pathways (Lee et al., 2004). It has been reported that lipid peroxidation inhibitors such as U-74006F, BN 82270 and tirilazad mesylate protect a variety cell lines and tissues (facial neuronal cell, glial cell and brain) against trophic deprivation-, toxic drug- and ischaemic reperfusion-induced insults by a combination of radical scavenging and membrane stabilizing properties (Hall et al., 1996; Auvin et al., 2004; Hall 1996). In the cochlea, antioxidant drugs can also prevent ototoxic drug(Rybak and Whitworth, 2005) and noise- (Henderson et al., 2006) induced hearing loss.

In a variety of cell lines, free radical damage can be accompanied by c-Jun-Nterminal kinase (JNK) and caspase-3 activation (Salh et al., 2000). In the cochlea, both the JNK pathway (Pirvola et al., 2000; Wang et al., 2003), and activation of caspase-3 (Nicotera et al., 2003; Shi and Nuttall 2003) are involved in hair cell loss induced by noise trauma. A caspase-independent pathway involving endoG translocation to the nucleus after noise trauma has also been reported (Yamashita et al., 2004). Finally, intracellular calcium and calcium buffering mechanisms are implicated in noise-induced cochlear cell damage. Calcium influx can activate calpains, a family of calciumactivated proteases, which promote the breakdown of proteins, kinases, phophatases and transcription factors and receptors (Chan and Mattson, 1999; Sorimachi et al., 1996). Studies have shown that sound overstimulation increases intracellular calcium in hair cells in vitro (Fridberger et al., 1998) and causes an increase in calpain immunoreactivity in vivo (Wang et al., 1999). Consistent with this, when the calpain inhibitor leupeptin is perfused into the basal turn of the chinchilla cochlea, it reduces the amount of hair cell loss induced by sound overstimulation (Wang et al., 1999). 
Investigation of the production of specific breakdown products (FBDP) of substrates specific to calpain proteolysis has proved useful in detecting calpain activity in nervous and sensory tissues (Siman et al., 1984; Saido et al., 1993, 1994; Blomgren et al., 1995; Shields et al., 1999; Rajgopal and Vemuri, 2002; Ladrech et al., 2004 among others). Among these substrates, fodrin, the neuronal form of spectrin, is a specific actin cross-linking protein that is cleaved by calpain to a greater extent than other substrates. In the normal cochlea the presence of fodrin has been demonstrated in ,different cell types (Hafidi et al., 1990; Ylikoski et al., 1990; Slepecky and Ulfendahl, 1992; Nishida et al., 1993; Attanasio et al., 1994; Raphael et al., 1994; Kuhn and Vater, 1995; Mahendrasingam et al., 1998). In hair cells, fodrin is expressed in the cuticular plate (Pack and Slepecky, 1995) and along the lateral cell membrane (Holley and Ashmore, 1990). In this study, we used an antibody that specifically recognizes the 150kDa breakdown products of the fodrin-subunit specifically cleaved by calpain (see Saido et al., 1993, 1994, for review) to detect calpain activity in sound damaged cochlea.

The aim of our present study was thus to evaluate the therapeutic value of a novel dual inhibitor of calpains and lipid peroxidation (BN 82270, Auvin et al., 2006) on permanent hearing loss and hair cell loss induced by sound trauma. The dipeptide BN 82270 was perfused into the perilymphatic fluids through a hole made in the scala tympani of the basal turn, using an osmotic minipump. We show that BN 82270 prevents translocation of cytochrome $c$ from the mitochondria to the cytoplasm, DNA fragmentation, hair cell degeneration and permanent hearing loss. We have further shown that BN 82270 not only prevented the damage from occurring, but also rescued the cochlea when applied onto the round window membrane after sound trauma. 


\section{MATERIALS AND METHODS}

The care and use of animals followed the animal welfare guidelines of the « Institut National de la Santé et de la Recherche Medicale » (INSERM), under the approval of the French « Ministère de l'Agriculture et de la Forêt ». Experiments were conducted on female guinea pigs (250 to $300 \mathrm{~g}$, l'Arbresle, France).

\section{BN 82270 delivery and electrophysiological recordings}

All efforts were made to limit the number of animals used and their suffering. Animals were anesthetized with an intraperitonal (i.p.) injection of a $6 \%$ solution of sodium pentobarbital (Sanofi, Montpellier, France; $0.3 \mathrm{ml} / \mathrm{kg}$ ) and each bulla was exposed via a post-auricular approach. A recording electrode of insulated platinum wire was placed on the bone of the round window niche of both the left and right cochleae, and a reference electrode of non-insulated platinum wire was placed in a neck muscle.

\section{- Intracochlear delivery via an osmotic minipump -}

Prior to surgery, the Alzet 2001 minipump (DURECT Corp., Cupertino, CA) was filled with $200 \mu \mathrm{l}$ of artificial perilymph (AP) containing either $0.1,1,3.3,10$, 33, or $100 \mu \mathrm{M}$ of BN 82270 under sterile conditions ( $\mathrm{n}=6$ for each concentration tested, i.e., 36 animals). The tip of a glass perfusion pipette (attached by polyethylene tubing to the minipump) was inserted into a $0.2 \mathrm{~mm}$ hole that had been drilled close to the round window in the basal turn of the right cochlea. The minipump flow rate was $1 \mu \mathrm{L} / \mathrm{h}$, over a period of 7 days. 


\section{- RWM delivery via an osmotic minipump -}

We also evaluated the ability of $\mathrm{BN} 82270$ to rescue cochlear function from sound-induced hearing loss, when perfused onto the round window membrane (RWM) after the initial exposure to the sound trauma. Here, the minipump containing $300 \mu \mathrm{M}$ BN 82270 were implanted 48 before, or $1 \mathrm{~h}, 3 \mathrm{~h}, 6 \mathrm{~h}, 12 \mathrm{~h}, 24 \mathrm{~h}$ or $48 \mathrm{~h}$ after the initial exposure to the sound trauma ( $n=6$ for each time point, i.e., 42 animals). Particular attention was taken to avoid any interference with the electrode placed on the bone of the round window niche. The round window niche was perfused with $300 \mu \mathrm{M}$ of $\mathrm{BN}$ 82270 over 7 days.

\section{- Functional assessment -}

Compound action potentials (CAPs) of the auditory nerve were elicited by tone bursts $(2,4,6,8,10,12,16,20,26 \mathrm{kHz})$ of alternating polarity $(1 \mathrm{~ms}$ rise/fall, $8 \mathrm{~ms}$ duration) and applied to the ear at a rate of $10 / \mathrm{sec}$ from 0 to $100 \mathrm{~dB}$ SPL in $5 \mathrm{~dB}$ steps in a free field via a JBL 075 earphone. Cochlear responses were amplified (gain 2000), averaged (128 samples) and stored on a Pentium PC computer operating at 100 megahertz (Dell Dimension, USA). CAP thresholds were recorded before and 20 minutes, $1,3,5,10,15$ and 30 days after sound trauma. CAPs were measured peak-topeak, between the negative depression $\mathrm{N} 1$ and the subsequent positive wave $\mathrm{P} 1$. The threshold of the CAP was defined as the intensity in $\mathrm{dB}$ SPL needed to elicit a measurable response $(\geq 5 \mu \mathrm{V})$. 


\section{Sound trauma}

A continuous pure tone of $6 \mathrm{kHz}$ generated by a waveform synthesiser (HewlettPackard 8904A) was used to induce sound trauma. The guinea pigs were anaesthetized with an intraperitoneal injection of a $6 \%$ solution of sodium pentobarbital (Sanofi, Montpellier, France; dose- $0.3 \mathrm{ml} / \mathrm{kg}$ ) and exposed to $120 \mathrm{~dB} \mathrm{SPL}$ for 30 minutes, which was routed through a programmable attenuator and presented to the ears in free field via a JBL 075 earphone positioned $10 \mathrm{~cm}$ directly in front of the animal's head, which was immobilized in a non-invasive head holder. The sound level was measured using a calibrated 1/2" Bruel and Kjaer microphone (model 4314) and a Bruel and Kjaer calibrating amplifier (model 2606).

\section{Scanning electron microscopy assessment}

After the electrophysiological session (30 days following the sound trauma), 6 animals $(100 \mu \mathrm{M}$ BN82270 perfused sound-exposed cochleae and contralateral unperfused sound-exposed cochleae, 6 cochleae per group) were re-anaesthetized, decapitated and both cochleae were immediately removed. The cochleae were fixed, and prepared for scanning electron microscopy as described elsewhere (Wang et al., 2002). Quantitative evaluation of sensory hair cell loss was performed by counting missing hair cells from the apex to the base of the cochleae according a method previously used in different pathological conditions including acoustic trauma (HunterDuvar, 1977) and ototoxicity (Aran et al., 1982). In normal conditions, the guinea pig cochlea is around $20 \mathrm{~mm}$ long (Engström et al., 1966) and contains approximately 2000 inner hair cells (IHCs) and $2500 \times 3$ outer hair cells (OHCs). For cell counts, the whole cochlear duct was assessed in segments each $1 \mathrm{~mm}$ in length, which would contain an 
expected number of $100 \mathrm{IHCs}$ and $125 \times 3$ OHCs in each segment (100\%). The number of missing IHCs and OHCs was counted in each $1 \mathrm{~mm}$ segment. Hair cells were counted as absent if the stereociliary bundle and the cuticular plate were absent. When the stereociliary bundle was present, the cell was considered as present even if a few stereocilia were fused. Cytocochleograms represent the percentage of remaining hair cells in each row of hair cells (IHCs, OHCs1, 2, 3) over the whole length of the cochlea.

\section{Transmission Electron Microscopy}

Two additional animals (4 sound-exposed cochleae) were decapitated during deep anesthesia at 30 days after noise exposure, and their cochleae were removed and prepared using our standard protocol for epoxy resin embedding (Puel et al., 1994). Then, the cochleae were processed as flat epoxy preparations (Spoendlin and Brun, 1973). In each samples, transverse ultrathin sections of the organ of Corti were cut from the area of maximal damage (at around $14 \mathrm{~mm}$ from the apex) and from more apical regions, tonotopically corresponding to frequencies comprised between $4 \mathrm{kHz}$ and $2 \mathrm{kHz}$ (between $11 \mathrm{~mm}$ and $9 \mathrm{~mm}$ from the apex). The sections were stained with uranyl acetate and lead citrate and observed using a Hitachi 7100 electron microscope (Hitachi, Tokyo, Japan) at Centre de Ressources d'Imagerie Cellulaire de Montpellier.

\section{Immunocytochemistry.}

The mechanism of cochlear hair cell death and any protective effect of BN 82270 against sound trauma were tested using immunocytochemistry. BN 82270 was perfused into the cochleae via an osmotic minipump for 7 days, and the animals were implanted with this minipump 2 days prior to sound exposure. 
In this series of experiments, Terminal TdT-mediated dUTP-biotin nick end labelling (the TUNEL method) was performed on non-exposed animals $(n=2)$ and 1,6 , 24, 48 and 72 hours after sound exposed on the perfused (100 $\mu \mathrm{M} B N$ 82270) and unperfused cochleae of each animal ( $\mathrm{n}=2$ for each time point). Cleavage of fodrin by calpains was studied using immunostaining in perfused cochleae 24 hours after sound trauma (100 $\mu \mathrm{M}$ BN 82270, $\mathrm{n}=3)$ and in unperfused cochleae prior to and 1, 6, 24, 48 and 72 hours ( $\mathrm{n}=2$ for each time point) after sound trauma. Cytochrome $\mathrm{c}$ was studied using immunocytochemistry in non-exposed animals $(n=3)$ and one hour after sound trauma in animals' perfused (100 $\mu$ M BN 82270, $n=3)$ and unperfused cochleae $(n=3)$.

The cochleae were quickly removed and fixed with $4 \%$ paraformaldehyde in $0.1 \mathrm{M}$ - $\mathrm{pH} 7.2$ phosphate buffered saline (PBS), then immersed in the same fixative for two hours. Cochleae were rinsed in $0.1 \mathrm{M}$ PBS. The surface preparation of the organ of Corti was exposed by removing the otic capsule, the stria vascularis and the tectorial and Reissner's membranes. $10 \mu \mathrm{m}$ thicknesses of cochlea cryostat sections were prepared after micro dissection.

\section{- Cleavage of fodrin -}

Calpains specifically cleave the $240-k D$ fodrin subunit in repeat 11 , between residues $\mathrm{Y} 1176$ and $\mathrm{G} 1177$, to produce a $150-\mathrm{kD}$ fodrin breakdown product (FBDP). In the present study, we used a polyclonal antibody specific to the 150-kD FBDP developed by Saido et al. (1993) on surface preparations taken from the 4 cochlear turns, i.e., basal turn (from the round window to $8 \mathrm{~mm}$ ), middle1 ( 8 to $13 \mathrm{~mm}$ ); middle 2 (13 to $17 \mathrm{~mm}$ ) and the apical turn from 17 to $20 \mathrm{~mm}$. Antibodies (1:400) against FBDP 
cleaved by calpains were employed in double-labeling assays together with an anticalbindin antibody (1:600, mouse monoclonal, C9848, Sigma, St. Louis, MO). Labeling of calbindin enabled us to identify the hair cells (Dechesne and Thomasset, 1988; Pack and Slepecky, 1995). Cleavage products of fodrin were detected using a Tyramide Signal Amplification (TSA Fluorescence System kit, NEN Life Science Products, Boston, MA), according to the manufacturer directions. Secondary antibodies were a biotynilated anti-rabbit antibody (1:300, P.A.R.I.S, Compiègne, France) together with a Cy3-conjugated goat anti-mouse IgG antibody (1:500, Jackson ImmunoResearch Labs, West Grove, PA). The fluorescent tags were visualized with confocal microscopy (BioRad, Hercules, CA, USA). In control specimens in which the primary antibodies were omitted, neither FITC nor CY3 fluorescent tags were observed.

\section{- Release of cytochrome c -}

The cryostat sections were immunostained with a mouse anti-cytochrome $c$ monoclonal antibody (1:200; Pharmingen International, San Jose, CA, USA). Secondary antibody was a FITC-conjugated goat anti-mouse IgG antibody (1:200, B13113C, Biosys, Compiegre, France). The FITC fluorescence tag was visualized using a confocal microscope (Bio-Rad, Hercules, CA, USA).

\section{Apoptotic assessment}

The surface preparations from the 4 cochlear turns were stained to detect DNA fragmentation in the nuclei of apoptotic cells using the TUNEL technique (an ApopTag ${ }^{\mathrm{TM}}$ in situ apoptosis detection kit and fluorescein, Intergen, Purchase, NY, USA). Briefly, residues of digoxigenin-deoxyribonucleotide triphosphate were added catalytically to the 
3'-OH ends of DNA using TdT on surface preparations. The incorporated digoxigeninnucleotides were then immunostained with a FITC-conjugated anti-digoxigenin antibody from the TUNEL kit. The tissues were counterstained with propidium iodide (PI). The FITC and PI fluorescent signals were observed with a MRC 1024 laser scanning confocal microscope equipped with a $15 \mathrm{~mW}$ krypton/argon laser (Bio-Rad, Hercules, CA, USA).

\section{Statistics}

All quantitative results are expressed as means \pm SEM. All statistics were calculated using Sigma plot 2000 for Windows (version 6.1). All comparisons between means were performed using Student's paired two-tail $t$ tests or a nonparametric Wilcoxon rank test.

\section{RESULTS}

\section{Functional and morphology assessments}

The study was designed to evaluate any therapeutic effect BN 82270 may have on permanent threshold shift (PTS) and hair cell loss induced by sound trauma. 94 female pigmented guinea pigs were exposed to intense sound $(6 \mathrm{kHz}, 120 \mathrm{~dB} S P L$ for 30 min.) under anesthesia. Although differences between ears in individual animals might exist, we minimised the risk of working on animals which presented spontaneous recovery to normal thresholds by using the contralateral ear as an internal control. Based on these criteria, 13 animals were excluded from the study because the control 
contralateral cochlea spontaneously recovered normal auditory thresholds within the 5 days following sound trauma. Consequently, 81 animals demonstrating PTS were used in this study.

\section{- Effect of sound exposure alone -}

The average hearing loss (means \pm SEM) measured 20 min after sound exposure

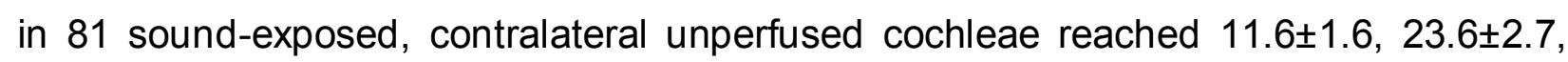
$39.6 \pm 2.5,53.3 \pm 2,60.7 \pm 1.2,58.8 \pm 1.6,54.3 \pm 1.8,51.8 \pm 1.7,42.6 \pm 2 \mathrm{~dB}$ at $2,4,6,8,10$, 12, 16, 20 and $26 \mathrm{kHz}$ respectively, with a maximum temporary hearing loss achieved between the frequencies of 8 and $16 \mathrm{kHz}$. Over 48 hour after sound trauma, CAP thresholds partially recovered, No further significant improvement in hearing threshold levels occurred over the remaining month of the experiment. When CAP threshold measured at 48 hours were compared with CAP thresholds measured 30 days after sound trauma, no differences were seen across frequency $(p>.05)$. CAP thresholds measured at 30 days were $5.1 \pm 1.1,14.3 \pm 1.7,26.4 \pm 2.1,37.2 \pm 1.7,36.4 \pm 1.5,28 \pm 1.7$, $14.9 \pm 2.1,6.3 \pm 1.3$ and $4.6 \pm 0.8 \mathrm{~dB}$ at $2,4,6,8,10,12,16,20$ and $26 \mathrm{kHz}$, respectively, with the maximum PTS occurring between 8 and $12 \mathrm{kHz}$.

\section{- BN82270 prevents noise-induced hearing loss -}

When the cochleae were perfused with BN82270 at a concentration of $100 \mu \mathrm{M}$, the immediate elevation of hearing thresholds induced by sound trauma was similar (i.e., 50 to $60 \mathrm{~dB}$ between 8 and $16 \mathrm{kHz}$ ) in both ears. Two days after sound exposure, threshold shift in the perfused ears was significantly lower than in the control contralateral ears. In addition, no subsequent deterioration in thresholds was observed in the perfused ears 
over the next 28 days (Fig. 1A). Since maximal PTS was seen at $10 \mathrm{kHz}$, analysis data were then performed at $10 \mathrm{kHz} 30$ days after sound trauma. When compared with preexposure threshold from the same ear, significant improvements were seen in the CAP thresholds for all concentrations of BN82270 above $1 \mu \mathrm{M}$ (Fig. 1B). There was a $5.8 \pm 5$ $\mathrm{dB}$ hearing loss in response to treatment with $10 \mu \mathrm{M}$ of $\mathrm{BN} 82270$, and $0.8 \pm 3.2 \mathrm{~dB}$ and $6.6 \pm 3.3 \mathrm{~dB}$ hearing loss at the highest concentration of 33 and 100 microM respectively (Fig. 1B). The concentrations of BN82270 in the scala tympani required to prevent $50 \%$ of the permanent threshold shift caused by exposure to the sound trauma paradigm were $4.69,5.05,4,07$ and $5.29 \mu \mathrm{M}$ for $6,8,10$ and $12 \mathrm{kHz}$ respectively. Same results were obtained when hearing loss in the perfused ear were compared with those in the

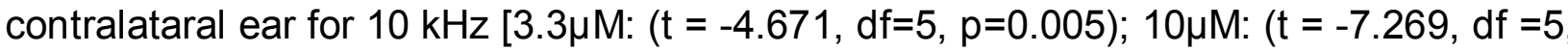
$p=0.0007) ; 33 \mu M(t=-7.682, d f=5, p=0.0005) ; 100 \mu M(t=-10.849, d f=5, p=0.0001)]$.

\section{- BN 82270 prevents noise-induced hair cell loss -}

Scanning electron microscopic observation of the surface morphology of each organ of Corti was performed at the end of the physiological survey of hearing thresholds, i.e., 30 days after sound trauma. In the noise-exposed, unperfused contralateral cochleae, a loss of both IHCs and OHCs was found in the area located 13 to $16 \mathrm{~mm}$ from the apex with a maximum of the HCs loss situated between 14 and 15 $\mathrm{mm}$ from the apex (Fig. 1C). This area corresponds to the position in the cochlear duct that code for frequencies between 8 to $12 \mathrm{kHz}$. Counting outer and inner hair cells present over the entire length of the cochlear duct allowed us to construct cochleograms for each type of hair cell in both contralateral sound-exposed, unperfused cochleae and the sound-exposed cochleae perfused with $100 \mu \mathrm{M}$ of BN82270. In the contralateral 
sound-exposed, unperfused cochleae most of the hair cell losses were found in the single row of $\mathrm{IHCs}$ and in the first row of OHCs, and to a lesser extent in the second and third rows of the OHCs (Fig. 1E). In this group $90.9 \%$ of the IHCs, $82.8 \%$ of the OHCs1, $41.4 \%$ of the $\mathrm{OHCs} 2$ and $36.4 \%$ of the $\mathrm{OHCs} 3$ were lost in the maximally damaged area (14 $\mathrm{mm}$ from the apex) by 30 days after the initial sound trauma.

Transmission electron microscopy assessment was also performed 30 days after sound exposure. When compared with the non-exposed control organ of Corti (Fig. 2A), the sound damaged organs of Corti (Fig. 2B) appeared to lack all hair cells in the narrow region of maximal damage (around $14 \mathrm{~mm}$ from the apex). In this region, the outer hair cells were replaced by apical expansions of the Deiters cells, the spaces of Nuels were reduced and the inner hair cell was replaced by hypertrophied inner supporting cells, the phalangeal and the first border cells (Fig. 2B). In more apical regions (between 11 and $9 \mathrm{~mm}$ from apex) which grossly correspond to the area of reception comprised between $4 \mathrm{kHz}$ and $2 \mathrm{kHz}$ (Eldredge, 1974; Rydmarker and Horner 1991), the sound induced damage was less pronounced. The outer hair cells had apparently normal stereocilia, but they showed lateral membrane invaginations (Fig. 2C) with typical disorganization of the cistern lamellae (Fig. 2D). In addition, abnormally dark medial efferent endings were seen at their basal pole (Fig. 2E). The shape of the inner hair cell (Fig. 2F) was generally normal although some of them showed a vacuolated cytoplasm. Afferent synapses were present at their basal pole (insert in Fig. 2F).

In contrast to the site of extensive focal damage documented in these unprotected cochleae, perfusion of $100 \mu \mathrm{M}$ of $\mathrm{BN} 82270$ for 2 days prior to and for 5 days following 
sound trauma exposure provided a significant level of protection to OHCs and IHCs present in that area that was maximally stimulated by the sound trauma exposure paradigm (Fig. 1D). Scala tympani perfusion with $100 \mu \mathrm{M}$ BN 82270 for 2 days prior to, during and for 5 days after sound exposure clearly resulted in a protective effect on both the IHCs and OHCs from the permanent effects of sound trauma. In this group, only $9.6 \%$ of the IHCs and $7 \%$ of OHCs $1,9.1 \%$ of OHCs 2 and $7 \%$ of OHCs 3 were missing in the area of the sound-induced lesion (Fig. 1F), which is consistent with the physiological data that showed almost no PTS.

\section{Immunocytochemical evaluations}

In this series of experiments, the immunocytochemical and TUNEL methods were used to determine the mechanism of cochlear hair cell death and any protective effect of BN 82270 against sound trauma.

\section{- BN82270 prevents - Cleavage of fodrin by calpains -}

Fodrin is a major component of the cuticular plate of auditory hair cells and a known substrate for effector caspases and calpains. Using an antibody specific for the $150 \mathrm{kDa} \mathrm{N}$-terminal large fragment of fodrin cleaved by calpains, we looked for its presence in sound-exposed cochleae. Calpain-cleaved fodrin was never detected in the cochlear cells in control, non-sound exposed cochleae (data not shown), or in apical regions of the sound exposed cochleae (Fig. 3A). In contrast, in the acoustically traumatised animals, observed between 6 and 48 hours after sound exposure, there was marked immunostaining for cleaved fodrin in the region of the cuticular plates of some OHCs and a few IHCs located in the area of maximal cochlear damage (Fig. 3B). 
Perilymphatic perfusion of BN 82270 at $100 \mu \mathrm{M}$ concentration prevented this cleavage of fodrin in hair cells in guinea pigs exposed to sound trauma (Fig. 3C), suggesting that calpains have been activated by sound trauma.

\section{- BN82270 prevents release of cytochrome c -}

To determine the downstream targets of calpain activation, we then investigated localisation of cytochrome $\mathrm{c}$ in sound trauma damaged cells by immunostaining. In the control non-sound-exposed cochleae, immunolabeling for cytochrome c showed an unequal distribution of reaction product within the cytoplasm of the hair cells in a punctated pattern, which is consistent with the mitochondrial localisation of cytochrome c (data not shown). One hour after sound trauma, the same pattern of immunostaining for cytochrome c was seen in the apical regions from the contralateral sound exposed, unperfused cochleae (Fig. 3D). By contrast, the pattern of both inner and outer hair cell cytoplasm immunostaining for cyt. $c$ changed from punctated to a diffuse and very weak pattern of immunostaining in the basal, sound damaged regions from the contralateral sound exposed, unperfused cochleae (Fig. 3E). When compared with non-sound exposed control cochleae, the intensity of the staining was very weak, sometimes barely above background level. This suggests that cytochrome $\mathrm{c}$ had been released from the mitochondria into the cytoplasm of the sound damaged hair cells. Perilymphatic perfusion of $100 \mu \mathrm{M} \mathrm{BN} 82270$ prevented this dispersion of cytochrome c from the mitochondria to the cytoplasm in guinea pig hair cells following sound trauma (Fig. 3F). 


\section{- BN82270 prevents DNA fragmentation -}

To determine the nature of cell death, we performed TUNEL labeling in control non-sound-exposed cochleae, contralateral sound-exposed cochleae and soundexposed cochleae perfused with $100 \mu \mathrm{M}$ of BN82270. No TUNEL-positive cells were observed in any of the cochleae obtained from non-sound-exposed cochleae of the control animals (data not shown). Similarly, no positive cells were seen in apical regions of contralateral cochleae exposed to sound trauma (Fig. 3G). Basal regions of contralateral cochleae exposed to sound trauma (but not perfused with BN 82270) displayed TUNEL-labeled cell nuclei in the upper focal planes of the organ of Corti (i.e., the superficial regions of the surface preparation of the organ of Corti) as early as 1 hour after sound trauma, continuing up to 72 hours after the trauma (Fig. $3 \mathrm{H})$. It is thus likely that these labeled nuclei belong to hair cells rather than supporting cells, which are located in the deeper regions. The majority of these labeled nuclei were located in the area of maximal damage. In the cochleae that received perilymphatic perfusion of 100 $\mu \mathrm{M}$ BN 82270, no TUNEL-labeled nuclei were observed during the examination period between 1 and 72 hours after sound trauma (Fig. 3I).

\section{Therapeutic window of BN 82270}

We also wished to determine whether BN 82270 was able to rescue the cochlea when sound trauma had occurred. Consequently, we applied $300 \mu \mathrm{M}$ BN82270 onto the round window membrane using an osmotic minipump starting $48 \mathrm{~h}$ before or $1,3,6,12$, 24 or 48 hours after sound trauma and continuing over 7 days. Our results demonstrated that BN 82270 enhanced functional recovery in a time-dependent manner. No significant difference ( $p>0.05$, nonparametric Wilcoxon rank test) in the 
protective effect of BN 82270 was found whether the treatment started 48 hours before or 1 hour after the sound trauma $(10 \pm 1.8 \mathrm{~dB}$ and $5 \pm 2.3 \mathrm{~dB}$ PTS respectively). The protective effect progressively diminished as the time interval between sound trauma and start of treatment increased (Fig. 4A). In our model of sound trauma, a functional recovery of $50 \%$ was observed when BN 82270 was applied 6.19 hours after sound trauma. When applied 24 hours after sound trauma, the efficacy of BN 82270 decreased, leading to $38.3 \pm 2.7 \mathrm{~dB}$ hearing loss. Finally, administration of $\mathrm{BN} 82270$ 48 hours after sound trauma had no effect $(39.1 \pm 4.7 \mathrm{~dB}$ versus $40 \pm 2.5 \mathrm{~dB}$ hearing loss in perfused and unperfused sound exposed cochlea). These functional results were confirmed by quantitative analysis of the number of remaining hair cells (Fig. 4B).

\section{DISCUSSION}

When perfused into the cochlear perilymph, the dual inhibitor of calpains and lipid peroxidation BN 82270 prevents the formation of calpain-cleaved fodrin, translocation of cytochrome $\mathrm{c}$ and DNA fragmentation caused by sound trauma. Although it did not reduced temporary threshold shift, BN 82270 perfusion improved recovery of thresholds with almost no PTS at $48 \mathrm{~h}$ after sound trauma. Cytocochleograms prepared one month after sound trauma showed that perilymphatic perfusion of BN 82270 protected $90 \%$ of IHCs and OHCs destined to die.

\section{Pattern of structural and functional damage}

Noise trauma is known to induce hair cell loss mainly in the first row of OHCs followed by the row of IHCs and finally in the two outer rows of OHCs. In this study, the 
greatest hair cell losses were actually noted in the first row of OHCs and relatively few $\mathrm{IHCs}$ were missing when the cochleae were observed within $48 \mathrm{~h}$ of the noise trauma. However, when cochleae were observed at one month after trauma, the pattern of hair cell loss had changed. The number of missing IHCs was slightly greater than the number of missing $\mathrm{OHCs}$ in row 1 which itself was greater than the number of missing OHCs in row 2 and row 3. A similar pattern of hair cell damage after acoustic trauma has previously been described in the rabbit cochlea (Engström, 1983; Engström et al., 1983) but it appears quite unusual in the guinea pig where OHC losses are generally greater than IHC loss. The reasons for such a discrepancy are not clear. They may be related to our experimental method that used a high frequency pure tone $(6 \mathrm{kHz})$ for inducing the acoustic trauma whereas most other studies have used band noises generally centred upon 4 kHz (among others: Attanasio et al., 2001; Shizuki et al., 2002; Pourbakht and Yamasoba, 2003). The damage following a $6 \mathrm{kHz}$ traumatic sound occur more basally along the cochlear spiral than those resulting from a $4 \mathrm{kHz}$ band noise. It is possible that in the basal cochlear region, the IHCs' sensitivity to noise trauma could be exacerbated due to specific functional or structural properties. In fact, in the guinea pig cochlea, the IHCs have been shown to respond to the movement of the basilar membrane for high frequency tones whereas they respond to velocity for the low frequencies (Patuzzi and Yates, 1986, 1987). In addition, the mode of coupling of the $\mathrm{IHC}$ stereocilia with the tectorial membrane may be different between the basal region and the more apical one. For instance, in rats (Ross, 1974 and Lenoir et al., 1987) and cats (Hoshino, 1976), the IHC stereocilia are firmly attached to the under surface of the tectorial membrane while they are free in the middle and apical turn. If the same structural characteristics exist in the guinea pig cochlea, it would be expected that the 
IHCs of the basal cochlear regions would present a similar sensitivity to mechanical trauma as the OHCs in the first row.

The maximal structural damage observed in the traumatized cochleae was located in the segment lying $14-15 \mathrm{~mm}$ from the apex. Functionally, this region of the cochlear spiral corresponds to the location of frequencies between 8 and $12 \mathrm{kHz}$ when referring to the guinea pig frequency-place map established by Eldredge (1974) and Rydmarker and Horner (1991). This frequency range fits well with the expected location of damage produced by a $6 \mathrm{kHz}$ pure tone over-stimulation, as it would actually induce maximal hair cell loss around the $9 \mathrm{kHz}$ location, i.e., about half an octave higher than the frequency of the traumatic sound. In addition, this frequency range corresponds to the peak threshold shift exhibited by our sound traumatized guinea pigs that takes place between $8 \mathrm{kHz}$ and $12 \mathrm{kHz}$. In areas adjacent to the maximally damaged area, we report inner and outer hair cells with normal stereocilia and cuticular plates but showing distorted cell bodies, invagination of their lateral wall and occasional vacuolated cytoplasm. In addition, some efferent endings under the OHCs displayed a very high density of vesicles. Together, these changes may explain the slight hearing losses present at $2 \mathrm{kHz}(5.1 \pm 1.1 \mathrm{~dB}$ PTS $)$ and $4 \mathrm{kHz}(14.3 \pm 1.7 \mathrm{~dB}$ PTS). This underlies the limitation of SEM to evaluate hair cell loss, and the necessity of using TEM to fully document the effect of sound trauma.

\section{Mechanisms of calpain-induced hair cell death.}

Calpains, a family of $\mathrm{Ca}^{2+}$-dependent cytoplasmic cysteine proteases are activated through an increase in intracellular $\mathrm{Ca}^{2+}$ (Molinari and Carafoli, 1997). The two 
major calpain isoforms, $\mathrm{m}$ - and $\mu$-, differ in the amount of $\mathrm{Ca}^{2+}$ required for activation. Calpain is considered to be primarily responsible for both apoptosis (Nath et al., 1996) and necrosis (Wang et al., 1996), probably as a consequence of a loss of $\mathrm{Ca}^{2+}$ homeostasis (Squier et al., 1994). Previous studies have shown that acoustic overstimulation causes damage to cellular organelles such as the endoplasmic reticulum (Anichin et al., 1985; Lim and Melnick 1971), which then leads to $\mathrm{Ca}^{2+}$ release from those intracellular $\mathrm{Ca}^{2+}$ stores. $\mathrm{Ca}^{2+}$ ions can also enter through the transducer channels of hair cells during maintained deflections of the stereociliary bundle (Ohmori 1988; Denk et al., 1995; Lumpkin and Hudspeth 1995). Ikeda et al. (1988) found that acoustic trauma caused a 50 -fold increase of $\mathrm{Ca}^{2+}$ in the endolymph. The sustained increase in intracellular $\mathrm{Ca}^{2+}$ is toxic to cells through activation of numerous calcium-dependent enzymes such as calpains. There are reports indicating that m-calpain can also be phosphorylated and activated by ERK, one of three major mammalian MAPK subfamilies [ERK 1 and 2, the c-Jun NH2-terminal kinases (JNK), and the p38 kinases] at Ser50 both in vitro and in vivo even in the absence of millimolar concentration of $\mathrm{Ca}^{2+}$ (Glading et al., 2004). Calpains have been shown to act upstream (McCollum et al., 2002), or downstream of caspase activation and to contribute to the degradation phase of apoptotic cell death in HL-60 cells (Wood and Newcomb, 1999; Wood et al., 1998). Furthermore, a "calpain-cathepsin cascade" has been reported, in which activated calpains induce release of lysosomal cathepsins and subsequent cell death (Yamashima et al., 1998 ; Yamashima 2004).

Ladrech et al. (2004) have shown the presence of fodrin cleaved by calpains in hair cells damaged by amikacin, by using an antibody that specifically recognizes the 
150-kDa breakdown products of the fodrin $\alpha$-subunit cleaved by calpains (Saido et al. 1993). In the present study, the demonstration that calpain-cleaved fodrin accumulates in hair cells damaged by sound trauma naturally suggests an involvement of calpains in the degeneration of hair cells induced by sound trauma.

As previously reported (Wang et al., 2002), we found that sound trauma provoked release of cytochrome $\mathrm{c}$ from the inner matrix of damaged mitochondria into the cytoplasm of the hair cells located in the areas maximally stimulated by the sound trauma. Perilymphatic perfusion of $100 \mu \mathrm{M}$ BN 82270 prevented this dispersion of cytochrome $\mathrm{c}$ from the mitochondria to the cytoplasm in guinea pig hair cells following sound trauma. Together, these results suggest that calpains initiate the activation of the mitochondrial cell death signaling pathway.

The TUNEL method is a classic marker of apoptosis (Riss, 2001; Pavlovsky and Vagunda, 2003). Because positive TUNEL-labeled hair cell nuclei have been reported after sound trauma, several authors have proposed that the apoptotic process is the primary mechanism of hair cell degeneration induced by sound trauma (Wang et al., 2002; Hu et al., 2002; Cheng et al., 2005). However, detected DNA breaks can also be caused by cellular necrosis and autolysis (Gold et al., 1994; Grasl-Kraupp et al., 1995). Accordingly, we have previously reported that sound trauma exposure results in different phenotypes of cell degeneration such as apoptosis, autolysis and, to a lesser extent, necrosis. However, whatever the phenotypes, a common feature of sound damage to hair cells is mitochondrial alteration (Wang et al., 2002). 


\section{BN 82270 prevents sound-induced hearing and hair cell loss}

Our data shows that the BN 82270, a dipeptide which has well cell penetration (Pignol et al., 2006), is a potent agent $\left(E D_{50}=4.07 \mu M\right)$ in protecting hair cells from acoustic trauma. Leupeptin, a prototypic aldehyde inhibitor exhibits low cell permeability and also inhibits other cysteine proteases and the proteasome (Mehdi 1991; Sorimachi et al., 1997). In vitro, leupeptin protects cochlear and vestibular hair cells from gentamicin ototoxicity with a range of efficacy between 0.1 to $3 \mathrm{mM}$ (Ding et al., 2002). In vivo, $1 \mathrm{mg} / \mathrm{ml}$ leupeptin perfused into the scala tympani of the basal turn of chinchilla cochleae using an osmotic pump over 14 days, reduced $\mathrm{OHC}$ loss following a $105 \mathrm{~dB}$ SPL exposure by $60 \%$ (Wang et al., 1999).

Calpain inhibitor I and calpain inhibitor II are synthetic inhibitors with increased cell permeability. They possess a greater degree of specificity although at higher concentrations (e.g., mM levels) also inhibit other cysteine proteases (Mehdi 1991; Sorimachi et al., 1997). Calpain inhibitor I seems slightly more potent $(1.25 \mu \mathrm{M})$, complete protection was obtained on neurotrophin-withdrawn dissociated spiral ganglion neurons in culture with $1 \mathrm{mM}$ leupeptin and $25 \mu \mathrm{M}$ calpain inhibitor II (Cheng et al., 1999).

To date, the most potent compounds in protecting hair cells are the inhibitors of the MAPK/JNK pathway. For example, subcutaneous injection of CEP-1347, an agent that blocks the c-Jun-N-terminal kinase pathway at the level of the mixed lineage kinases (Harris et al, 2002), 2 hours before acoustic trauma resulted in a $20 \mathrm{~dB}$ permanent threshold shift elevation (as opposed to a $40 \mathrm{~dB}$ PTS in unperfused animals) and reduced hair cell loss by 60\% (Pirvola et al., 2000). Intracochlear perfusion of D- 
JNKI-1, another inhibitor of JNK kinase, which selectively blocks access of MAPK/JNK to their substrates within the nucleus (Bonny et al., 2001), 48 hours before sound trauma resulted in a maximum permanent hearing loss of $12 \mathrm{~dB}$ at $8 \mathrm{kHz}$ (as opposed to a $48 \mathrm{~dB}$ PTS in the contralateral, unperfused cochleae) and prevented more than 88 $\%$ of the IHC and OHC losses (Wang et al., 2003).

In this study, local delivery of BN 82270 prevented acoustic trauma-induced permanent hearing loss in a dose-dependent manner $\left(E D_{50}=4.07 \mu \mathrm{M}\right)$. The application of $100 \mu \mathrm{M}$ BN82270 resulted in protection of the hair cells from the effects of the noise trauma. Less than $10 \%$ of the hair cells were missing from the area of maximum noiseinduced damage (Fig. 1F), which is consistent with our physiological data which showed almost no permanent loss of hearing (less than $7 \mathrm{~dB}$ of PTS at all frequencies tested). Although we did not compared the protective effect of BN 82270 with an antioxydant and a specific calpain inhibor alone, the high potency of this compound may be explain by the dual action on calpains and lipid peroxidation acting in a synergistic manner (Auvin et al., 2006; Pignol et al., 2006).

In conclusion, this report shows that local application of BN 82270 is compatible with clinical practice (i.e., round window membrane delivery), it improves the functional recovery of the cochlea after sound trauma, and it abolishes the cytological stigmata of damaged cochlear hair cells when given within a therapeutic window of 24 hours after the sound trauma. This suggests that BN 82270 may be an interesting molecule to treat inner ear injuries using a system of local application, because this route is efficient and avoids potential side effects after systemic application.

\section{ACKNOWLEDGMENTS}


The authors want to thank the anonymous reviewers for their comments and constructive criticisms. Thanks to $\mathrm{S}$. Ladrech and N. Renard for their technique assistance and J.-L. Pasquier for art work. Confocal and electron microscopy were done using the facilities of Centre Régional d'Imagerie Cellulaire/Institut Universitaire de Recherche Clinique, Université Montpellier 1.

\section{REFERENCES}

Allen, R.T., Hunter III, W.J., Agrawal, D.K., 1997. Morphological and biochemical characterization and analysis of apoptosis. Pharmacol J Toxicol Methods 37, 215-218.

Anichin, V.F., Ivanova, V.F., Pavlov, VV., 1985. Ultrastructural changes in the receptor portion of the vestibular apparatus in response to noise. Arkh Anat Gistol Embriol 89, 29-35.

Aran, J.M., Erre, J.P., Guilhaume A, Aurousseau C. 1982.The comparative ototoxicities of gentamicin, tobramycin and dibekacin in the guinea pig. A functional and morphological cochlear and vestibular study. Acta Otolaryngol Suppl 390, 1-30.

Attanasio, O., Spongr, V.P., Henderson, D., 1994. Localization of F-actin and fodrin along the organ of Corti in the chinchilla. Hear Res 81, 199-207. 
Attanasio, G., Buongiorno, G., Piccoli, F., Mafera, B., Cordier, A., Barbara, M., Filipo, R., 2001. Laser Doppler measurement of cochlear blood flow changes during conditioning noise exposure. Acta Otolaryngol 121, 465-469.

Auvin, S., Pignol, B., Navet, E., Pons, D., Marin, J.G., Bigg, D., Chabrier, P.E., 2004. Novel dual inhibitors of calpain and lipid peroxidation. Bioorg Med Chem Lett. 14, 3825-3828.

Auvin, S., Pignol, B., Navet, E., Troadec, M., Carre, D., Camara, J., Bigg, D., Chabrier, P.E., 2006. Novel dual inhibitors of calpains and lipid peroxidation with enhanced cellular activity. Bioorg Med Chem Lett 16,1586-1589.

Blomgren, K., McRae, A., Bona, E., Saido, T.C., Karlsson, J.O., Hagberg, H., 1995 Degradation of fodrin and MAP 2 after neonatal cerebral hypoxic-ischemia. Brain Res 684, 136-142.

Bonny, C., Oberson, A., Negri, S., Sauser, C., Schorderet, D.F., 2001. Cell-permeable peptide inhibitors of JNK: novel blockers of beta-cell death. Diabetes 50,77-82.

Chan, S.L., Mattson, M.P., 1999. Caspase and calpain substrates: roles in synaptic plasticity and cell death. J Neuroscien Res 58, 167-190.

Cheng, A.G., Huang, T., Stracher, A., Kim, A., Liu, W., Malgrange, B., Lefebvre, P.P., Schulman, A., Van de Water, T.R., 1999. Calpain inhibitors protect auditory 
sensory cells from hypoxia and neurotrophin-withdrawal induced apoptosis. Brain Res 850,234-43.

Cheng, A.G., Cunningham, L.L., Rubel, E.W., 2005. Mechanisms of hair cell death and protection. Curr Opin Otolaryngol Head Neck Surg 13, 343-348.

Dechesne, C.J., Thomasset, M., 1988. Calbindin (CaBP 28 kDa) appearance and distribution during development of the mouse inner ear. Brain Res 468, 233-242.

Eldredge, D.H. 1974., Inner Ear-Cochlear mechanics and cochlear potentials. In: Keidel, W.D., and Neff, W.D., (Eds), Handbook of Sensory Physiology. Auditory System. VolV/1. Springer Verlag, Berlin, pp. 549-584.

Denk, W., Holt, J.R., Shepherd, G.M., Corey, D.P., 1995. Calcium imaging of single stereocilia in hair cells: localization of transduction channels at both ends of tip links. Neuron 15, 1311-1321.

Ding, D., Stracher, A., Salvi, R.J., 2002. Leupeptin protects cochlear and vestibular hair cells from gentamicin ototoxicity. Hear Res 164, 115-126.

Dive, C., Gregory, C.D., Phipps, D.J., Evans, D.L., Milner, A.E., Wyllie, A.H., 1992. Analysis and discrimination of necrosis and apoptosis (programmed cell death) by multiparameter flow cytometry. Biochim Biophys Acta 1133, 275-285. 
Engstrom, B., 1983. Stereocilia of sensory cells in normal and hearing impaired ears. A morphological, physiological and behavioural study. Scand Audiol Suppl 19,1-34.

Engstrom, B., Flock, A., Borg, E., 1983. Ultrastructural studies of stereocilia in noiseexposed rabbits. Hear Res. 12, 251-264.

Engstrom, H., Ades, H.W., Andersson, A., 1966. Structural pattern of the organ of Corti. Almqvist\& Wiksell, Stockholm.

Fridberger, A., van Maarseveen, J.T., Ulfendahl, M., 1998. An in vitro model for acoustic overstimulation. Acta Otolaryngol 118, 352-361.

Glading, A., Bodnar, R.J., Reynolds, I.J., Shiraha, H., Satish, L., Potter, D.A., Blair, H.C., Wells, A., 2004. Epidermal growth factor activates m-calpain (calpain II), at least in part, by extracellular signal-regulated kinase-mediated phosphorylation. Mol Cell Biol 24, 2499-2512.

Gold, R., Schmied, M., Giegerich, G., Breitschopf, H., Hartung, H.P., Toyka, K.V., Lassmann, H., 1994. Differentiation between cellular apoptosis and necrosis by the combined use of in situ tailing and nick translation techniques. Lab Invest 71, 219-225.

Grasl-Kraupp, B., Ruttkay-Nedecky, B., Koudelka, H., Bukowska, K., Bursch, W., Schulte-Hermann, R., 1995. In situ detection of fragmented DNA (TUNEL assay) 
fails to discriminate among apoptosis, necrosis, and autolytic cell death: a cautionary note. Hepatology 21, 1465-1468.

Hafidi, A., Despres, O., Romand, R., 1990. Cochlear innervation in the developing rat: an immunocytochemical study of neurofilament and spectrin proteins. J Comp Neurol 300, 153-161.

Hall, E.D., Smith, S.L., Oostveen, J.A., 1996. Inhibition of lipid peroxidation attenuates axotomy-induced apoptotic degeneration of facial motor neurons in neonatal rats. J Neurosci Res 44, 293-299.

Hall, E.D., 1996. Efficacy and mechanisms of action of the cytoprotective lipid peroxidation inhibitor tirilazad mesylate in subarachnoid haemorrhage. Eur $\mathrm{J}$ Anaesthesiol 13, 279-289.

Harris, C.A., Deshmukh, M., Tsui-Pierchala, B., Maroney, A., Johnson, Jr. E.M., 2002. Inhibition of the c-Jun N-terminal Kinase signaling pathway by the mixed lineage Kinase inhibitor CEP-1347 (KT7515) preserves metabolism and growth of trophic factor-deprived neurons. J Neurosci 22, 103-113.

Henderson, D., McFadden, S.L., Liu, C.C., Hight, N., Zheng, X.Y., 1999. The role of antioxidants in protection from impulse noise. Ann N Y Acad Sci 884, 368-380. 
Henderson, D., Bielefeld, E.C., Harris, K.C., Hu, B.H., 2006. The role of oxidative stress in noise-induced hearing loss. Ear Hear 27, 1-19.

Holley, M.C., Ashmore, J.F., 1990. Spectrin, actin and the structure of the cortical lattice in mammalian cochlear outer hair cells. J Cell Sci 96, 283-291.

Hoshino, T., 1976. Attachment of the inner sensory cell hairs to the tectorial membrane. A scanning electron microscopic study. ORL J Otorhinolaryngol Relat Spec 38, 11-18.

Hu, B.H., Guo, W., Wang, P.Y., Henderson, D., Jiang, S.C., 2000. Intense noiseinduced apoptosis in hair cells of guinea pig cochleae. Acta Otolaryngol 120, 1924.

Hu, B.H., Henderson, D., Nicotera, T.M., 2002. Involvement of apoptosis in progression of cochlear lesion following exposure to intense noise. Hear Res 166, 62-71.

Hunter-Duvar, I.,1977. Inner ear correlates in acoustic trauma. Trans Sect Otolaryngol Am Acad Ophthalmol Otolaryngol 84, 422.

Ikeda, K., Kusakari, J., Takasaka, T., 1988. Ionic changes in cochlear endolymph of the guinea pig induced by acoustic injury. Hear Res 32, 103-10. 
Kopke, R., Allen, K.A., Henderson, D., Hoffer, M., Frenz, D., Van de Water, T., 1999. A radical demise. Toxins and trauma share common pathways in hair cell death. Ann N Y Acad Sci 884, 171-191.

Kuhn, B., Vater, M., 1995. The arrangements of F-actin, tubulin and fodrin in the organ of Corti of the horseshoe bat (Rhinolophus rouxi) and the gerbil (Meriones unguiculatus). Hear Res 84, 139-156.

Ladrech, S., Guitton, M., Saido, T., Lenoir, M., 2004. Calpain activity in the amikacindamaged rat cochlea. J Comp Neurol 477, 149-160.

Lee, J.E., Nakagawa, T., Kita, T., Kim, T.S., Iguchi, F., Endo, T., Shiga, A., Lee, S.H., Ito, J., 2004. Mechanisms of apoptosis induced by cisplatin in marginal cells in mouse stria vascularis. ORL J Otorhinolaryngol Relat Spec 66, 111-118.

Lenoir, M., Puel, J.L., Pujol, R., 1987. Stereocilia and tectorial membrane development in the rat cochlea. A SEM study. Anat Embryol (Berl) 175, 477-487.

Le Prell, C.G., Dolan, D.F., Schacht, J., Miller, J.M., Lomax, M.I., Altschuler, R.A., 2003. Pathways for protection from noise induced hearing loss. Noise Health. 5,1-17.

Lim, D.J., Melnick, W., 1971. Acoustic damage of the cochlea. A scanning and transmission electron microscopic observation. Arch Otolaryngol 94, 294-305. 
Lumpkin, E.A., Hudspeth, A.J., 1995. Detection of Ca2+ entry through mechanosensitive channels localizes the site of mechanoelectrical transduction in hair cells. Proc Natl Acad Sci U S A 92, 10297-10301.

Mahendrasingam, S., Furness, D.N., Hackney, C.M., 1998. Ultrastructural localisation of spectrin in sensory and supporting cells of guinea-pig organ of Corti. Hear Res 126, 151-160.

McCollum, A.T., Nasr, P., Estus, S., 2002. Calpain activates caspase-3 during UVinduced neuronal death but only calpain is necessary for death. J Neurochem 82, 1208-1220.

Mehdi, S., 1991. Cell-penetrating inhibitors of calpin, TIBS 16,150-153.

Molinari, M., Carafoli, E., 1997. Calpain: a cytosolic proteinase active at the membranes. J Membr Biol 156, 1-8.

Nath, R., Raser, K. J., Stafford, D., Hajimohammadreza, I., Posner, A., Allen, H., Talanian, R. V., Yuen, P., Gilbertsen, R. B., Wang, K.K., 1996. Non-erythroid alpha-spectrin breakdown by calpain and interleukin 1 beta-converting-enzymelike protease(s) in apoptotic cells: contributory roles of both protease families in neuronal apoptosis. Biochem J 319, 683-690. 
Nicotera, T.M., Hu, B.H., Henderson, D.J., 2003. The caspase pathway in noise-induced apoptosis of the chinchilla cochlea. J Assoc Res Otolaryngol 4, 466-477.

Nishida, Y., Fujimoto, T., Tagaki, A., Honjo, I., Ogawa, K., 1993. Fodrin is a constituent of the cortical lattice in outer hair cells of the guinea pig cochlea: immunocytochemical evidence. Hear Res 65, 274-280.

Nordmann, A.S., Bohne, B.A., Harding, G.W., 2000. Histopathological differences between temporary and permanent threshold shift. Hear Res 139, 13-30.

Ohinata, Y., Miller, J.M., Altschuler, R.A., Schacht, J., 2000. Intense noise induces formation of vasoactive lipid peroxidation products in the cochlea. Brain Res 878, 163-173.

Ohlemiller, K.K., Wright, J.S., Dugan, L.L., 1999. Early elevation of cochlear reactive oxygen species following noise exposure, Audiol Neurootol 4. 229-236.

Ohmori, H., 1988. Mechanical stimulation and Fura-2 fluorescence in the hair bundle of dissociated hair cells of the chick. J Physiol 399, 115-137.

Pack, A.K., Slepecky, N.B., 1995. Cytoskeletal and calcium-binding proteins in the mammalian organ of Corti: cell type-specific proteins displaying longitudinal and radial gradients. Hear Res 91, 119-135. 
Patuzzi, R., Yates, G.K., 1986. Velocity and displacement coupling of mammalian inner hair cells and the mechanical resonance of the free-standing stereocilia. ORL $J$ Otorhinolaryngol Relat Spec 48, 81-86.

Patuzzi, R.B., Yates, G.K., 1987. The low-frequency response of inner hair cells in the guinea pig cochlea: implications for fluid coupling and resonance of the stereocilia. Hear Res 30, 83-98.

Pavlovsky, Z., Vagunda, V., 2003. Apoptosis--selected methods of detection of apoptosis and associated regulatory factors on tissue sections of tumors. Cesk Patol 39, 6-10.

Pignol, B., Auvin, S., Carré, d., Marin, J.G., Chabrier P.E., 2006. Calpain inhibitors and antioxidants act synergistically to prevent cell necrosis. Effects of the novel dual inhibitors (cysteine protease inhibitor and antioxidant) BN 82204 and its pro-drug BN 82270. Journal of Neurochemistry 98, 1217-1228.

Pirvola, U., Xing-Qun, L., Virkkala, J., Saarma, M., Murakata, C., Camoratto, A.M., Walton, K.M., Ylikoski, J., 2000. Rescue of hearing, auditory hair cells, and neurons by CEP-1347/KT7515, an inhibitor of c-Jun N-terminal kinase activation. J Neurosci 20, 43-50.

Pourbakht, A., Yamasoba, T., 2003. Cochlear damage caused by continuous and intermittent noise exposure. Hear Res 178, 70-78. 
Puel, JL, Pujol R., Tribillac, F., Ladrech, S., Eybalin, M., 1994 Excitatory amino acids antagonists protect cochlear auditory neurons from excitotoxicity. J Comp Neurol $341,241-256$.

Rajgopal, Y., Vemuri, M.C., 2002. Calpain activation and alpha-spectrin cleavage in rat brain by ethanol. Neurosci Lett 321, 187-191.

Raphael, Y., Athey, B.D., Wang, Y., Lee, M.K., Altschuler, R.A., 1994. F-actin, tubulin and spectrin in the organ of Corti: comparative distribution in different cell types and mammalian species. Hear Res 76, 173-187.

Riss, T.L., 2001. Apoptosis as a biomarker in chemoprevention trials. Urology 57, 141142.

Ross, M.D., 1974. The tectorial membrane of the rat. Am J Anat 139, 449-481.

Rybak, L.P., Whitworth, C.A., 2005. Ototoxicity: therapeutic opportunities.Drug Discov Today. 10, 1313-1321.

Rydmarker, S., Horner, K.C., 1991. Atrophy of outer hair cell stereocilia and hearing loss in hydropic cochleae. Hear Res 53,113-122. 
Saido, T.C., Yokota, M., Nagao, S., Yamaura, I., Tani, E., Tsuchiya, T., Suzuki, K., Kawashima, S., 1993. Spatial resolution of fodrin proteolysis in postischemic brain. J Biol Chem 268, 2523-2543.

Saido, T.C., Sorimachi, H., Suzuki, K., 1994. Calpain: new perspectives in molecular diversity and physiological-pathological involvement. FASEB J 8, 814-822.

Salh, B.S., Martens, J., Hundal, R.S., Yoganathan, N., Charest, D., Mui, A., GomezMunoz, A., 2000. PD98059 attenuates hydrogen peroxide-induced cell death through inhibition of Jun N-Terminal Kinase in HT29 cells. Mol Cell Biol Res Commun 4, 158-165.

Searle, J., Kerr, J.F., Bishop, C.J., 1982. Necrosis and apoptosis: distinct modes of cell death with fundamentally different significance. Pathol Annu 2, 229-259.

Shi, X., Nuttall, A.L., 2003. Upregulated iNOS and oxidative damage to the cochlear stria vascularis due to noise stress. Brain Res 967, 1-10.

Shields, D.C., Schaecher, K.E., Saido, T.C., Banik, N.L., 1999. A putative mechanism of demyelination in multiple sclerosis by a proteolytic enzyme, calpain. Proc Natl Acad Sci U S A 96, 11486-11491. 
Shizuki, K., Ogawa, K., Matsunobu, T., Kanzaki, J., Ogita, K., 2002. Expression of c-Fos after noise-induced temporary threshold shift in the guinea pig cochlea. Neurosci Lett 320, 73-76.

Siman, R., Baudry, M., Lynch, G., 1984. Brain fodrin: substrate for calpain I, an endogenous calcium-activated protease. Proc Natl Acad Sci U S A 81, 3572 3576.

Slepecky, N.B., Ulfendahl, M., 1992. Actin-binding and microtubuleassociated proteins in the organ of Corti. Hear Res 57, 201-215.

Squier, M. K., Miller, A. C., Malkinson, A. M., Cohen, J.J., 1994. Calpain activation in apoptosis J Cell Physiol 159, 229-237.

So, H.S., Park, C., Kim, H.J., Lee, J.H., Park, S.Y., Lee, J.H., Lee, Z.W., Kim, H.M., Kalinec, F., Lim, D.J., Park, R., 2005. Protective effect of T-type calcium channel blocker flunarizine on cisplatin-induced death of auditory cells. Hear Res 204, $127-139$.

Sorimachi, H., Kimura, S., Kinbara, K., Kazama, J., Takahashi, M., Yajima, H., Ishiura, S., Sasagawa, N., Nonaka, I., Sugita, H., Maruyama, K., Suzuki, K., 1996. Structure and physiological functions of ubiquitous and tissue-specific calpain species. Muscle-specific calpain, p94, interacts with connectin/titin. Adv Biophys 33, 101-122. 
Sorimachi, H., Ishiura, S., Suzuki, K., 1997. Structure and physiological function of calpains. Biochem J 328, 721-732.

Spoendlin, H., Brun, JP., 1973. Relation of structural damage to exposure time and intensity in acoustic trauma. Acta Otolaryngol 75, 220-226.

Wang, J., Ding, D., Shulman, A., Stracher, A., Salvi, R.J., 1999. Leupeptin protects sensory hair cells from acoustic trauma. Neuroreport 10, 811-816.

Wang, J., Dib, M., Lenoir, M., Vago, P., Eybalin, M., Hameg, A., Pujol, R., Puel, J.L.,2002. Riluzole rescues cochlear sensory cells from acoustic trauma in the guinea-pig. Neuroscience 111, 635-648.

Wang, J., Van De Water, T.R., Bonny, C., de Ribaupierre, F., Puel, J.L., Zine, A., 2003. A peptide inhibitor of c-Jun $\mathrm{N}$-terminal kinase protects against both aminoglycoside and acoustic trauma-induced auditory hair cell death and hearing loss. J Neurosci 23, 8596-8607.

Wang, K., Nath, R., Raser, K. J., Hajimohammadreza, I., 1996. Maitotoxin induces calpain activation in SH-SY5Y neuroblastoma cells and cerebrocortical cultures. Biochem Biophys 331, 208-214. 
Wood, D.E., Thomas, A., Devi, L.A., Berman, Y., Beavis, R.C., Reed, J.C., Newcomb, E.W., 1998. Bax cleavage is mediated by calpain during drug-induced apoptosis. Oncogene 17, 1069-1078.

Wood, D.E., Newcomb, E.W., 1999. Caspase-dependent activation of calpain during drug-induced apoptosis. J Biol Chem 274, 8309-8315.

Wyllie, A.H., Kerr, J.F.R., Currie, A.R., 1980. Cell death: the significance of apoptosis. Int Rev Cyt 68, 251-306.

Yamane, H., Nakai, Y., Takayama, M., Iguchi, H., Nakagawa, T., Kojima, A., 1995. Appearance of free radicals in the guinea pig inner ear after noise-induced acoustic trauma, Arch Otorhinolaryngol 252, 504-508.

Yamashima, T., Kohda, Y., Tsuchiya, K., Ueno, T., Yamashita, J., Yoshioka, T., Kominami, E., 1998. Inhibition of ischaemic hippocampal neuronal death in primates with cathepsinBinhibitorCA-074: a novel strategy for neuroprotection based on "calpain-cathepsin hypothesis." Eur J Neurosci 10, 1723-1733.

Yamashita, D., Miller, J.M., Jiang, H.Y., Minami, S.B., Schacht, J., 2004. AlF and EndoG in noise-induced hearing loss. Neuroreport 15, 2719-2722. 
Yamashima, T., 2004. Ca2+-dependent proteases in ischemic neuronal death: a conserved "calpain-cathepsin cascade" from nematodes to primates. Cell Calcium. 36, 285-293.

Yamasoba, T., Harris, C., Shoji, F., Lee, R.J., Nuttall, A.L., Miller, J.M., 1998. Influence of intense sound exposure on glutathione synthesis in the cochlea, Brain Res. 804, 72-78.

Ylikoski, J., Pirvola, U., Narvanen, O., Virtanen, I., 1990. Nonerythroid spectrin (fodrin) is a prominent component of the cochlear hair cells. Hear Res 43,199-203. 


\section{LEGENDS TO FIGURES}

Figure 1. BN 82270 prevented permanent hearing loss and hair cell loss. A: Intracochlear perfusion of $100 \mu \mathrm{M}$ of $\mathrm{BN} 82270$ on cochlear functional recovery measured 30 days after sound trauma. Shown are hearing loss from contralateral unperfused, sound-exposed, left cochleae (open circles) and the sound-exposed right cochleae perfused with a $100 \mu \mathrm{M}$ solution of BN 82270 (filled circles) from the same animals $(n=6)$. Contralateral unperfused (control) cochleae displayed a permanent hearing loss. In contrast, a significant improvement in recovery of hearing function was seen in those cochleae perfused with $100 \mu \mathrm{M}$ of $\mathrm{BN} 82270$, leading to almost normal thresholds. B: Dose-dependent effects of BN 8227030 days after sound trauma. Hearing loss at $10 \mathrm{kHz}$ was calculated as the difference in hearing thresholds measured before and 30 days after sound exposure, within the same perfused ear. Each point is expressed as means \pm SEM from 6 animals. Dose-response data were then fitted to a curve using a non-linear least-square logistic equation. The Boltzman equation was used for fitting sigmoid curves. The $E_{50}$ was calculated as $4.07 \mu \mathrm{M}$. C and D: Scanning electron micrographs of areas of sound trauma damage (14-15 mm from apex) in cochleae from the same sound-exposed animal. Note that direct delivery of 100 $\mu \mathrm{M}$ of BN 82270 into the scala tympani effectively prevented sound trauma-induced hair cell loss (in D). E and F: Quantitative analysis of hair cell damage consisted of counting all hair cells along the entire length of the cochlear ducts. Cochleograms represent the mean survival of hair cells as the function of the distance from the apex (in $\mathrm{mm}$ ) in contralateral unperfused cochleae $(n=6)$ and in the $100 \mu \mathrm{M}$ BN 82270-perfused cochleae $(n=6)$ of the same animals. Sound exposure caused a narrow band of hair cell 
trauma in the cochleae located $13-16 \mathrm{~mm}$ from the apex. In the damaged area of the contralateral unperfused cochleae, the most severe damage was observed in IHCs (I) and the first row of $\mathrm{OHCs}(\mathrm{O})$ with a gradation of damage in the second and the third rows of OHCs (in E). In contrast, less than $10 \%$ of the hair cells loss were seen in the maximally damaged area from the cochleae that were treated with a local application of a $100 \mu \mathrm{M}$ solution of $\mathrm{BN} 82270$ (in $\mathbf{F}$ ). In $\mathrm{E}$ and $\mathrm{F}$, all points represent mean $\pm \mathrm{SEM}$ values calculated from the 6 animals. p: pillar cells. Scale bars: $C$ and $D=20 \mu \mathrm{m}$.

Figure 2 : Intense sound induced ultrastructural changes in the organ of Corti. A: Normal aspect of the organ of Corti in a control non-sound-exposed cochlea (light microscopy). The three outer hair cells $(01,02,03)$ are surrounded by the spaces of Nuels. Both outer hair cells and inner hair cell (I) are separated by the tunnel of Corti (tC). Arrows show the stereocilia of the inner and outer hair cells. (D: Deiters cells; bm: basilar membrane). B: Ultrastructural changes (transmission electron microscopy) in the sound traumatized area (around $14 \mathrm{~mm}$ from the apex) of organ of Corti observed one month after sound exposure. Both the outer and inner hair cells are absent. The outer hair cells are replaced by apical expansions of their supporting cells, the Deiters cells. The spaces of Nuels are greatly reduced. The inner hair cell is replaced by its two supporting cells, the phalangeal cell $(p)$ and the first border cell (b). C-F: Ultrastructural changes in a more apical region (around $10 \mathrm{~mm}$ from the apex) of the sound damaged organ of Corti. C: In this micrograph, outer hair cell from the first row is missing and the two remaining outer hair cells (O2 and $\mathrm{O} 3$ ) show distorted cells bodies and lateral membrane invagination (asterisks). Note the normal appearance of the stereocilia (arrows) on the remaining outer hair cells (O2 and O3). D: Higher magnification of the 
apical pole of the outer hair cell from the third row (O3) shown in C. The lateral membrane is invaginated (asterisk) and the underlying cistern lamellae are disorganised (arrowheads). E: Higher magnification of the basal pole of the outer hair cell from the second row $(\mathrm{O} 2)$ shown in $\mathrm{C}$. The cell is contacted by two large efferents $(\mathrm{e} 1, \mathrm{e} 2)$ and one afferent ending (a). Both efferents have numerous mitochondria. One efferent (e2) is abnormally dark due to vesicles accumulation. $\mathbf{F}$ : The inner hair cell is essentially well shaped, has normal stereocilia (arrow) and its basal pole is contacted by nerve endings The arrowhead in the basal pole of the inner hair cell points out a synaptic body at the level of an IHC-afferent synapse (arrowhead). An enlargement of the synapse is shown in the insert. Note the presence of the synaptic body (arrowhead) within the inner hair cell (I), facing the afferent ending (a). Scale bars: A, B, C, F = $10 \mu \mathrm{m} ; \mathrm{D}, \mathrm{E}=5 \mu \mathrm{m}$.

Figure 3. BN 82270 prevented calpain-cleaved fodrin, translocation of cytochrome c and DNA fragmentation. A to C: Immunolabeling of fodrin cleaved by calpains on whole-mount surface preparations at $24 \mathrm{~h}$ post-sound trauma. In $\mathbf{A}$, the apical turn from a sound-exposed animal, almost all hair cells are visible and labeled for calbindin (red), and no immunoreactivity for the anti-fodrin cleaved by calpain (green) is seen. In B, the basal turn from a sound-exposed animal, numerous OHCs have already disappeared in the three rows of OHCs. All the remaining hair cells are labeled for calbindin (red) and six OHCs are double-labeled for fodrin cleaved by calpains (green). Note the cuticular plates are strongly immunoreactive for the anti-fodrin cleaved by calpain antibody but the cell bodies are essentially unlabeled. In $\mathbf{C}$, the basal turn from sound-exposed cochleae perfused with $100 \mu \mathrm{M}$ BN 82270. Note that all hair cells are visible, and no immunoreactivity for the anti-fodrin cleaved by calpain is seen. $\mathbf{D}$ to $\mathbf{F}$ : 
Confocal micrographs of transverse cryostat sections of the apical or basal turns of the organ of Corti, stained by immunocytochemistry for cytochrome c, one hour after acoustic trauma. In $\mathbf{D}$, the apical turn from a sound-exposed animal shows intense punctate staining for cytochrome c. In E, the basal turn from a sound-exposed animal, immunostaining for cytochrome $c$ is diffuse in the cells in the sound-damaged area. In F, a basal turn from sound-exposed cochlea perfused with $100 \mu \mathrm{M} B N 82270$ displays intense punctate staining for cytochrome $\mathrm{c}$ in the hair cells, similar to the control nontraumatised cochlea. G to I: TUNEL staining of whole mounts of epithelium of organ of Corti. Epithelium harvested 24 hours after sound trauma. DNA strand breaks are stained fluorescent green by FITC-labeled dUTP; nuclei are counter-stained red with propidium iodide; TUNEL-labeled nuclei appear yellow. In G, epithelium from an apical turn of a sound exposed cochlea. No TUNEL-labeled nuclei are seen. In $\mathbf{H}$, note the presence of TUNEL-labeled nuclei in the OHCs and IHC region from a basal turn of a sound-exposed cochlea. In I, epithelium from the basal turn of a sound-exposed, perfused (with $100 \mu \mathrm{M}$ BN 82270) cochlea. There are no TUNEL-labeled nuclei in the $\mathrm{OHC}$ or IHC; the epithelium of the organ of Corti is similar to that of the normal cochlea. Scale bars: $\mathrm{A}$ to I $=35 \mu \mathrm{m}$.

Figure 4. Time-dependent effects of round window perfusion of BN 82270 .

A: Functional recovery 30 days after sound trauma. The treatment commenced 48 hours before or $1,3,6,12,24$ or 48 hours after sound trauma. Hearing loss at $10 \mathrm{kHz}$ was calculated as the difference in hearing thresholds measured before and 30 days after sound exposure, within the same perfused ear. Time-response data were then fitted to a curve using a non-linear least-square logistic equation. The Boltzman equation was 
used for fitting sigmoid curves. Each point is expressed as means \pm SEM from 6 animals. When applied 6 hours after sound exposure, BN82270 prevents $50 \%$ of the hearing loss. BN 82270 is ineffective when treatment is started after 12 hours. B: Quantitative analysis of hair cell damage from the contralateral unperfused cochleae $(n=3)$ and the cochleae perfused with $300 \mu$ M of BN 82270 perfused through the intact round window membrane $1(n=3), 6(n=3), 12(n=3)$ and 24 hours $(n=3)$ after sound trauma. Note that BN 82270 prevents $80 \%$ of hair cell loss (both inner and outer hair cells) when BN82270 is applied 6 hours after sound trauma. No longer efficiency was noticed when applied 24 hours later. All points represent mean \pm SEM. values calculated from 3 cochleae. 

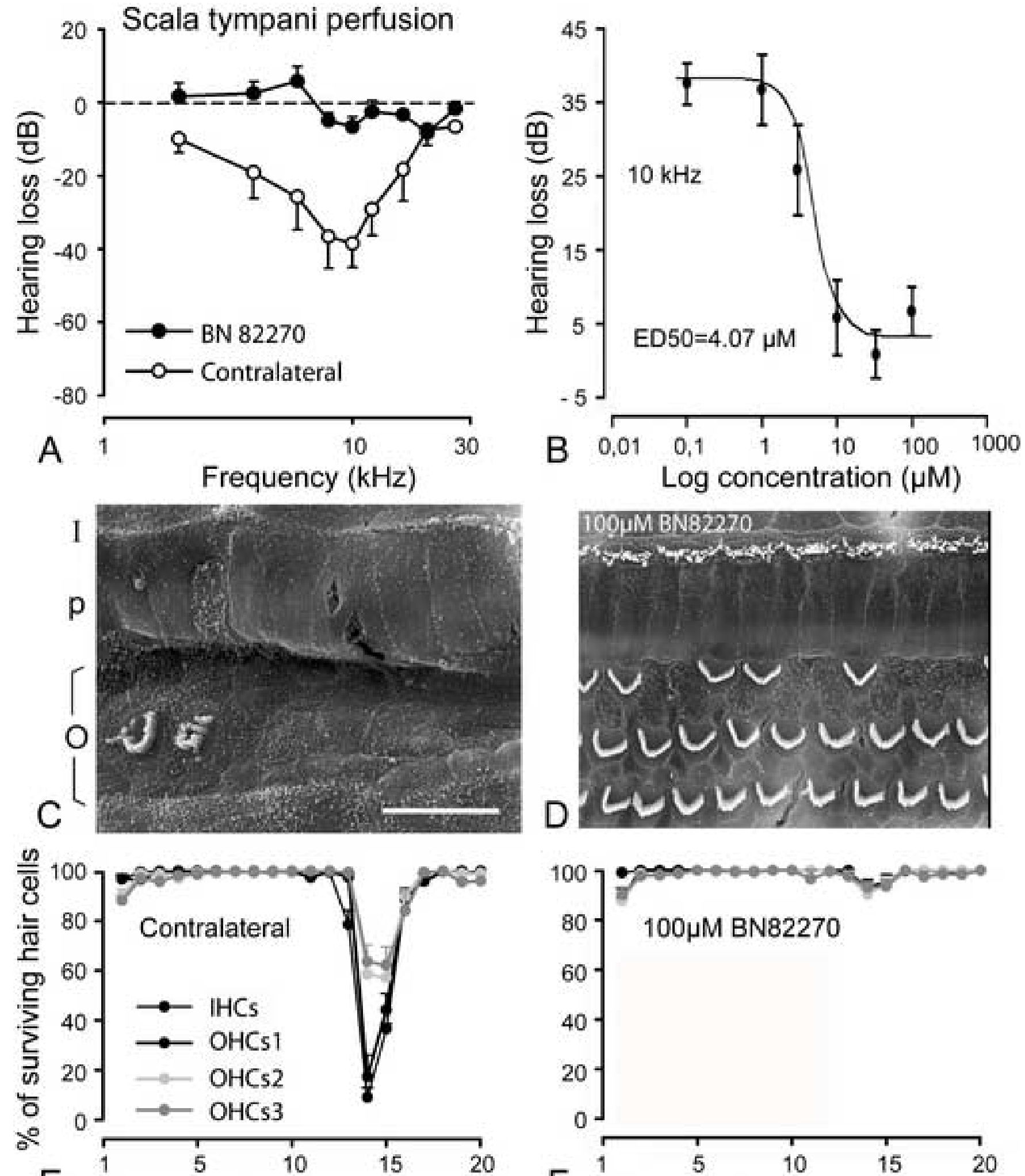

E Distance from the apex $(\mathrm{mm})$

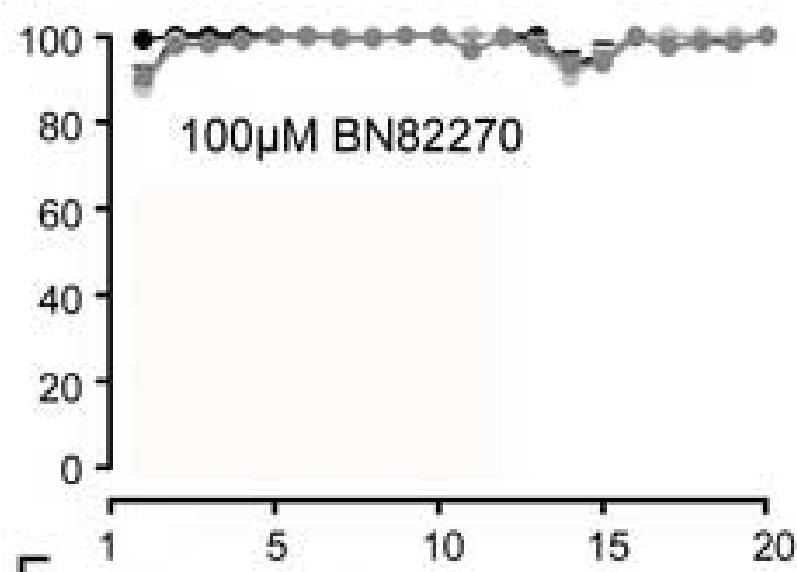

F Distance from the apex $(\mathrm{mm})$ 

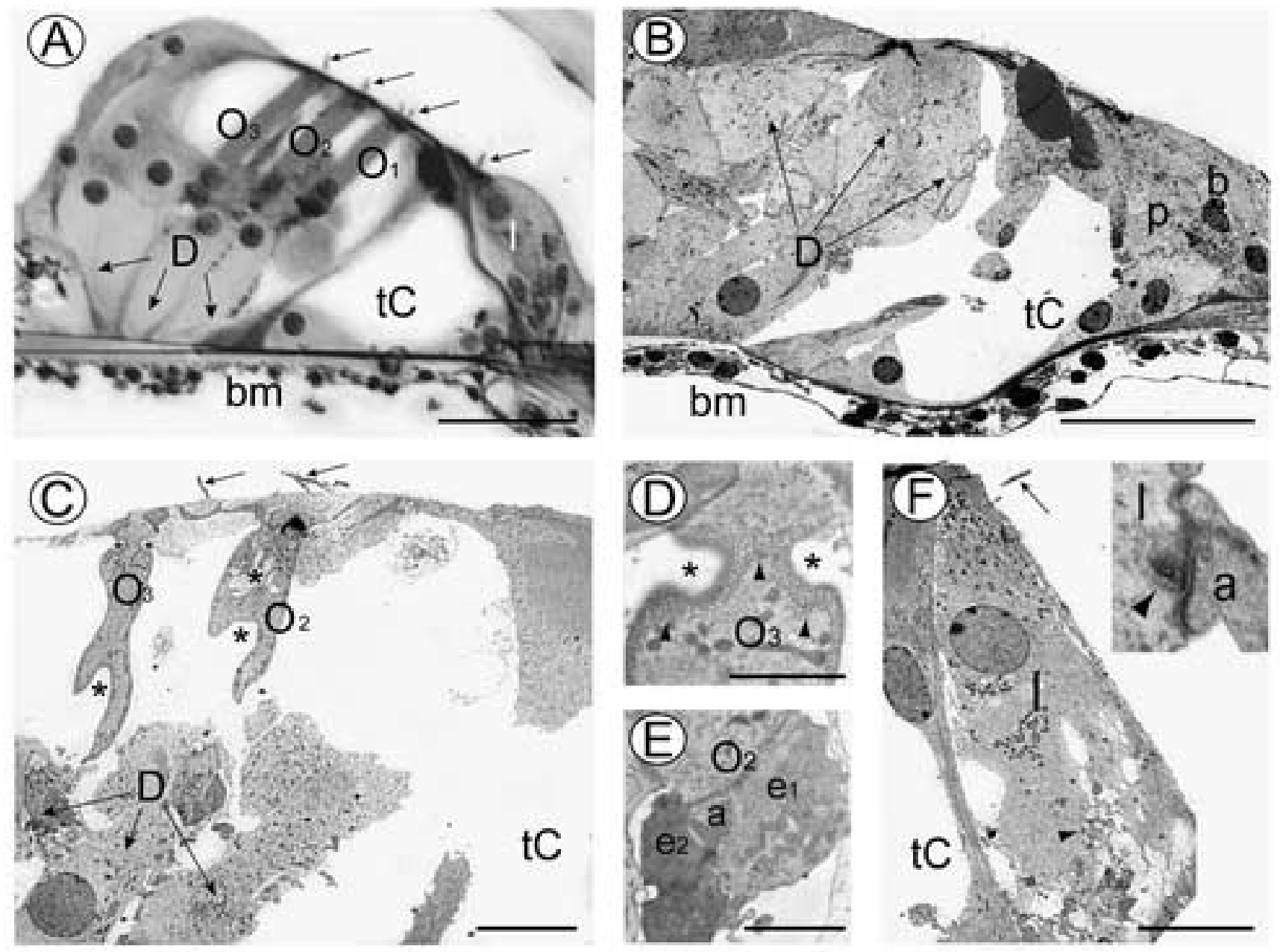
Trauma, apex
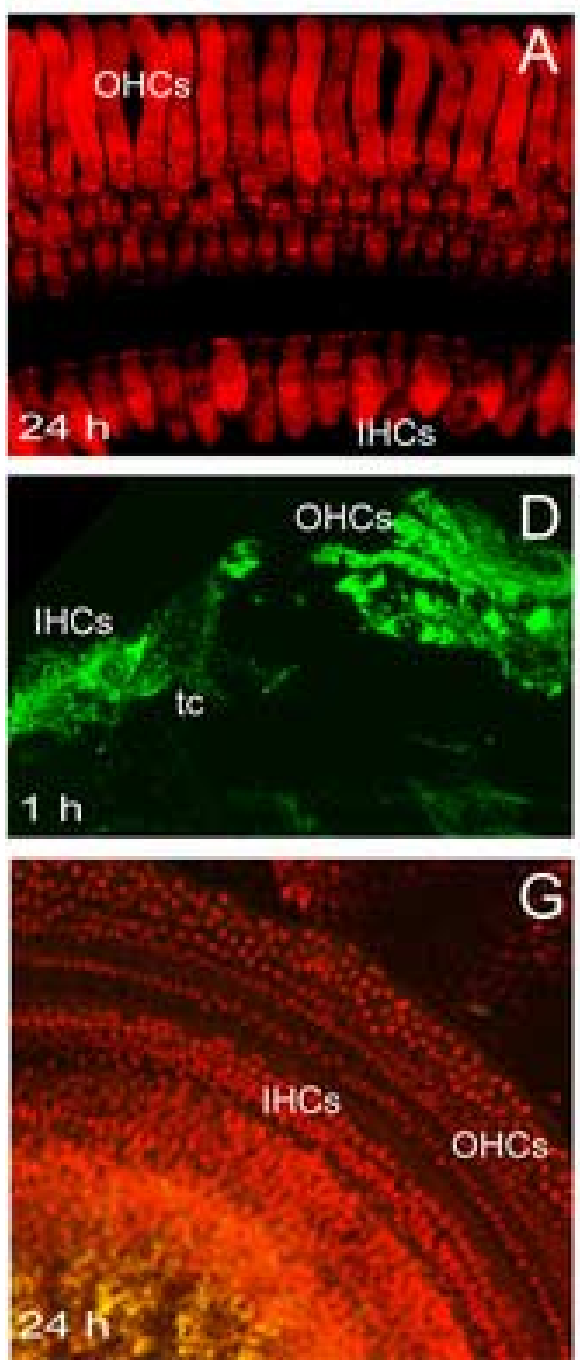

Trauma, base
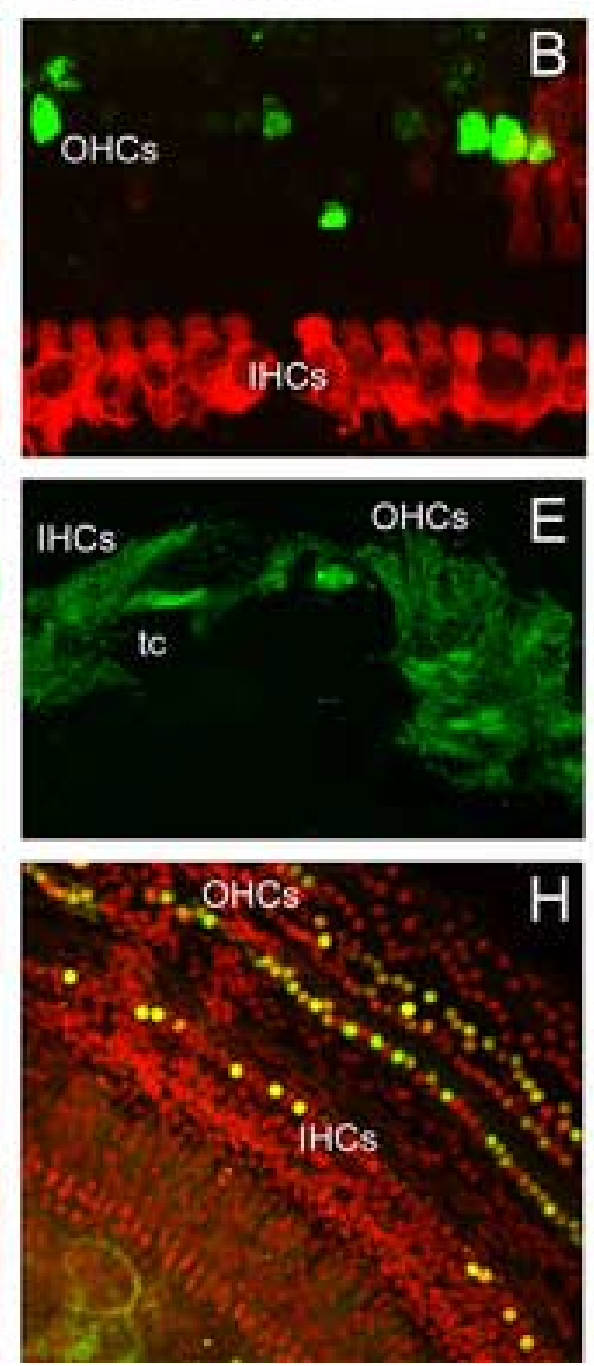

Trauma + BN 82270, base
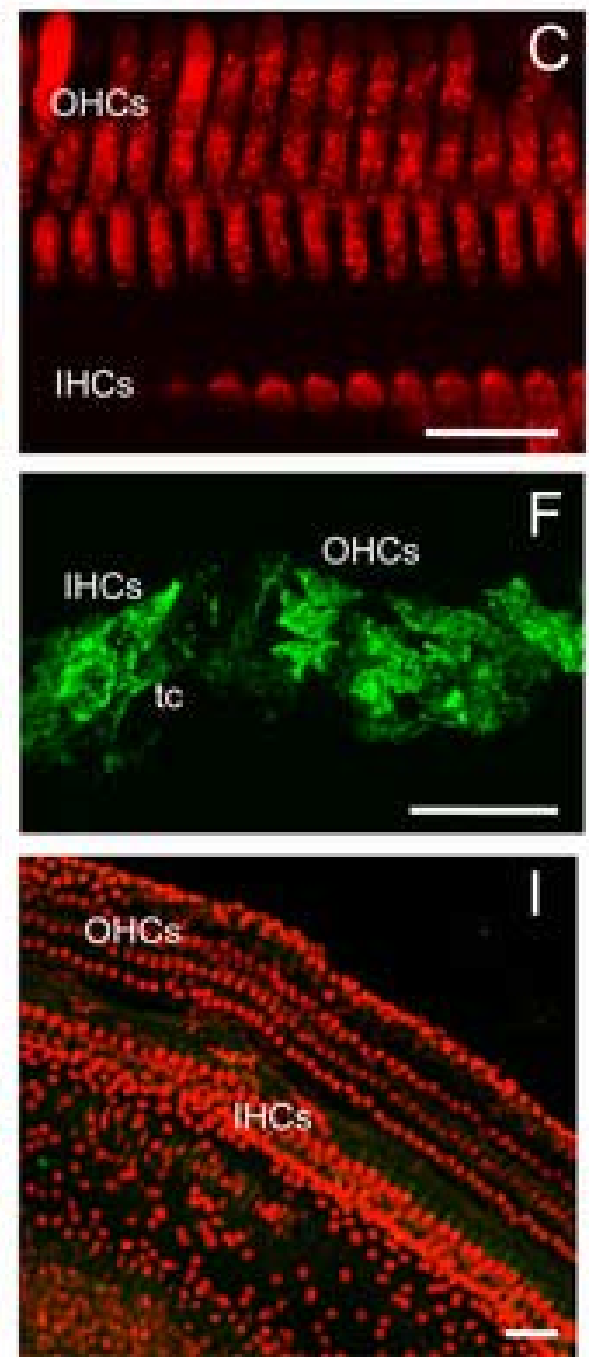

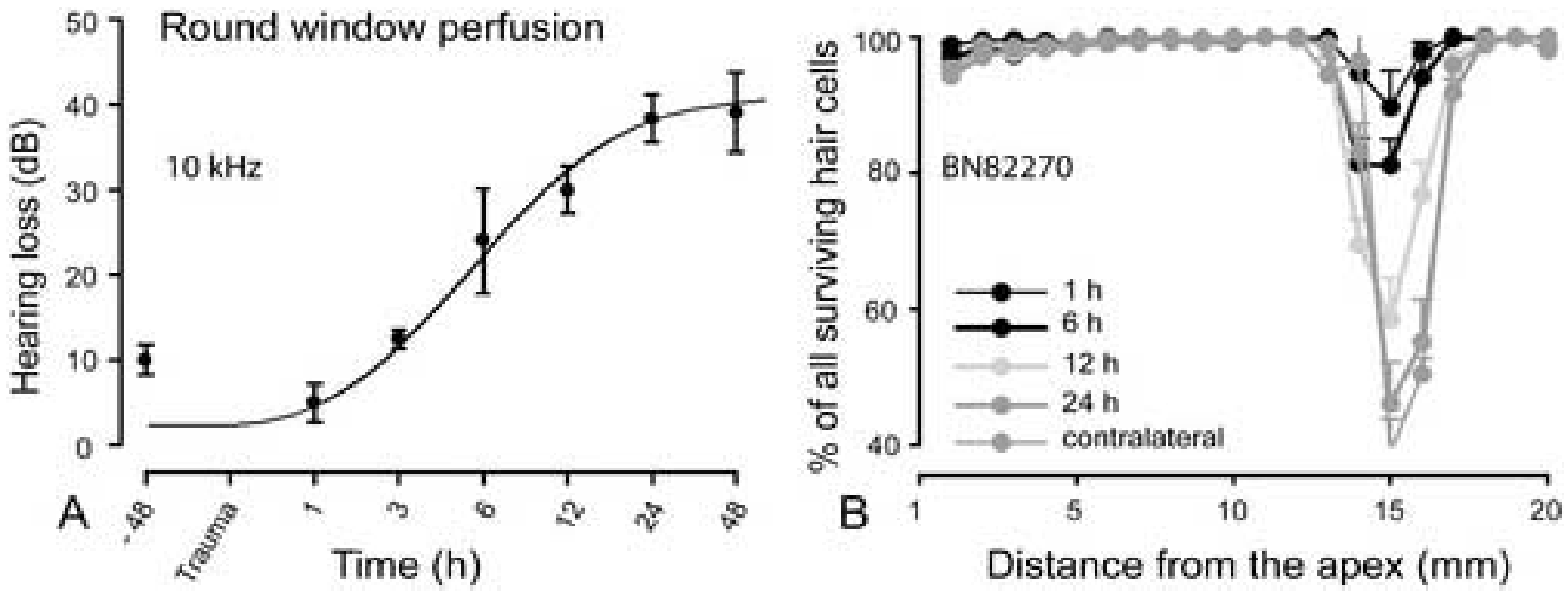


\section{${ }^{*}$ Response to Reviewers}

\section{Reviewer}

\section{Comments to the Authors}

The authors have addressed many of my concerns, and the manuscript has been improved in many ways. For example, the introduction is now more specific and detailed, and the methods have been clarified very well.

Authors'an swer:

We appreciate the positive evaluation of reviewer for the substantial changes we provide.

\section{Comments to the Authors}

However, several major issues with this study remain to be addressed.

1. Hair cell counts showing IHC loss exceeding OHC loss are from only three animals. The authors have adequately clarified their hair cell counting procedures, and I am satisfied that the unusual results they present are not due to any problem with their preparations or their assessment procedures. In response to my earlier concerns, the authors added details to the methods section and discussed possible reasons for the unusual results in the discussion section. These changes are definite improvements in the manuscript. However, the problem remains that the cochleogram results are based on an as sessment of cochleas from only 3 animals.

\section{Au thors'answer:}

To address this criticism, we have performed hair cell counting in 3 additional animals, leading to a total of 6 animals. As done in the previous experiments, the sound-exposed, non-perfused cochlea served as control to verify the effect of sound trauma, whereas the sound-exposed perfused cochea served to evaluate any protective effect of BN82270. Increasing the number of animals did not change the observed pattern of hair cell loss.

See results section (line 3, page 15) and new figure $1 \mathrm{E}$ and $\mathrm{F}$. "In this group $90.9 \%$ of the IHCs, $82.8 \%$ of the OHCs $1,41.4 \%$ of the OHCs 2 and $36.4 \%$ of the OHCs 3 were lost in the maximally damaged area (14 $\mathrm{mm}$ from the apex) by 30 days after the initial sound trauma."

\section{Comments to the Authors}

The authors suggest that the use of a $6 \mathrm{kHz}$ tone rather than narrow band noise is a likely reason why similar results have not been reported previously in guinea pigs. While the points raised concerning differential sensitivity of basal vs. apical IHCs in the discussion are good points to make, it seems to me that this is not an adequate explanation because previous studies that have used $6.3 \mathrm{kHz}$ tones (e.g., Canlon et al.) have still found greater OHC loss than IHC loss in guinea pigs.

\section{Authors' answer:}

The reviewer focuses on the greater sensitivity to sound of the IHC versus the OHC. In fact, the difference between IHC loss and loss from the first row of OHCs is not particularly great $(90.9 \%$ for IHCs versus $82.8 \%$. for the OHCs 1$)$. In addition, it is difficult to compare our data with others. The pure tone frequency used by Canlon et $a l$. is close $(6.3 \mathrm{kHz})$. However, compared to Can lon's exposure, the intensity of our sound exposure is much higher (120 versus $100 \mathrm{~dB}$ SPL) and the duration much shorter (30 min. versus $24 \mathrm{~h}$ ). This may explain the slight difference of pattern of hair cell loss, reported herein. 


\section{Comments to the Authors}

The main problem is that the results in the current study are based on a VERY small sample (only THREE cochleas). Just how representative were these 3 cochleas of the rest of the animals in this study, and of guinea pigs in general? My main concern is the inadequate sample size here, which is a point I raised previously. The study used 78 guinea pigs. Only 3 cochleas were used for the analysis of hair cell loss that formed the basis for several broad conclusions regarding protection. If 6 animals were used for physiological measures with this dose and at this time point, why weren't all 12 cochleas included in the histological analyses? In their response, the authors suggest that this small number $(n=3)$ is adequate because each animal provided it's own control. This position is indefensible from a statistical standpoint. Despite the within-subject design, with animals providing both treated and control cochleas, an $n$ of 3 is simply inadequate, particularly given the interanimal variability in sensitivity to noise that the authors acknowledge. The number of cochleas examined for hair cell counts must be increased to provide an adequate sample in this study. Related to this, the authors have added SEM values to the means, but again, this is based on $n=3$. Statistically, it is not defensible to use such a small sample to represent a variable population and it is not appropriate to calculate SEM based on 3 individuals from the population.

\section{Au thors answer:}

Because we agree with the reviewer, we have performed hair cell counting in 3 additional animals. Therefore, we now provide results from the histological analysis of 12 cochleae, or 6 cochleae for each condition: sound-exposed non-perfused and sound-exposed BN82270-perfused cochleae (this point has also been addressed in point 1).

\section{Comments to the Authors}

2. The issue of how to account for hearing loss at frequencies with no hair cell loss was not addressed. Several of my previous comments were aimed at getting the authors to address the discrepancy between hair cell loss and hearing loss (PTS). In other words, what accounts for hearing loss at frequencies where there was NO hair cell loss? The authors adequately defended and clarified their use of frequency/place maps in their response. However, they never addressed in the revised discussion how PTS occurred in regions far removed from regions with damaged hair cells. The cochleograms show very clearly defined damage patterns, with HCs missing in a narrow range but NONE missing above or below this region, even though PTS was observed at frequencies as low as $2 \mathrm{kHz}$. The authors should comment on the discrepancy between hair cell loss and hearing loss in the discussion.

\section{Au thors answer:}

The reviewer's comment is very pertinent. To solve the discrepancy between hair cell loss and hearing loss (PTS) at $2 \mathrm{kHz}$, we performed additional morphological investigations using transmission electron microscope in 2 animals (4 cochleae). Ultrastructural analysis demonstrates that in areas adjacent to the maximally damaged area, inner and outer hair cells can have the appearance of normal stereocilia and cuticular plates but show distorted cell bodies, invagination of their lateral wall and occasional vacuolated cytoplasm. As indicated in the methods section (line 2, page 9): "hair cells were counted as absent if the stereociliary bundle and the cuticular plate were absent. When the stereociliary bundle was present, the cell was considered as present even if a few stereocilia were fused". This underlies the limitation of SEM to evaluate hair cell loss, and the need of TEM to fully document the effect of sound trauma. 
This point has been also mentioned in the discussion (page 21, line 13).

"In areas adjacent to the maximally damaged area, we report inner and outer hair cells with normal stereocilia and cuticular plates but showing distorted cell bodies, invagination of their lateral wall and occasional vacuolated cytoplasm. In addition, some efferent endings under the OHCs displayed a very high density of vesicles. Together, these changes may explain the slight hearing losses present at $2 \mathrm{kHz}$ $(5.1 \pm 1.1 \mathrm{~dB}$ PTS $)$ and $4 \mathrm{kHz}(14.3 \pm 1.7 \mathrm{~dB}$ PTS $)$. This underlies the limitation of SEM to evaluate hair cell loss, and the necessity of using TEM to fully document the effect of sound trauma."

\section{Comments to the Authors}

3. Animals may have been selected in a manner that biases results in favor of finding a protective effect of BN82270. The authors state that 13 animals with normal thresholds in the CONTROL ear were excluded from the study, in order to "demonstrate more clearly a protective effect of BN82270." In no ise exposure studies, it is not uncommon to have differences between right and left ears of an exposed animal, and it is not inconceivable that treated ears will on occasion have more PTS than control ears. I question the decision to exclude animals from the study unless reasons are clearly justified. I am wondering how many of the animals that were excluded because thresholds in their untreated control ears were normal actually had hearing loss in their other ear? Given the issue of variability in the effects of noise exposure, the more defensible approach is to increase power by increasing sample size, not to exclude subjects that don't show the effect you want. If the 13 animals with normal thresholds in the control ears ALSO had normal thresholds in the treated ear, then the decision to exclude them from analysis MAY be more defensible, but unless this is shown and stated, the decision to exclude cases needs more defense.

\section{Au thors answer:}

We excluded the animals with spontaneous threshold recovery to normal because "The aim of our present study was thus to evaluate the therapeutic value of a novel dual inhibitor of calpains and lipid peroxidation (BN 82270, Auvin et al., 2006) on permanent hearing loss and hair cell loss induced by sound trauma" (see line 16, page 5). In others words, there is no rationale in developing a therapeutic approach for a deafness that fully recovers. Moreover, keeping animals in the study who show spontaneous threshold recovery may distort the therapeutic window of BN82270, particularly the time efficacy of the drug which would be polluted by any spontaneous recovery.

The misunderstanding is probably due to the fact that we state that we exclude animals to clearly demonstrate any protective effect of BN82270, which is not true. What we wanted to avoid was to work on animals presenting spontaneous recovery to normal thresholds. We do not deny that differences between ears in individual animals may exist, but the use of the contralateral ear as an internal control to verify the effect of trauma allows us to minimise the risk of working on animals who go on to recover hearing to normal thresholds. So, we have clarified this point in the first paragraph of the results:

\section{Line 18 , page 12}

"The study was designed to evaluate any therapeutic effect BN 82270 may have on permanent threshold shift (PTS) and hair cell loss induced by sound trauma. 94 female pigmented guinea pigs were exposed to intense sound $(6 \mathrm{kHz}, 120 \mathrm{~dB}$ SPL for 30 min.) under anesthesia. Although differences between ears in ind ividual animals might exist, we minimised the risk of working on animals which presented spontaneous 
recovery to normal thresholds by using the contralateral ear as an internal control. Based on these criteria, 13 animals were excluded from the study because the control contralateral cochlea spontaneously recovered normal auditory thresholds within the 5 days following sound trauma. Consequently, 81 animals demonstrating PTS were used in this study."

\section{Comments to the Authors}

4. The results are presented as RECOVERY when they are DIFFERENCES between right and left ears, not recovery. The authors continue to present results as "improvements" and "recovery" when they are showing differences between right and left ears at a given point in time. This is incorrect and misleading. The authors have clarified that "recovery" refers to differences between the treated and untreated ears in PTS. Again, it is not appropriate to refer to this between-ear comparison as "recovery," and all references to "recovery" should be changed to indicate that they were differences between the two ears, not a change over time in one ear

\section{Authors answer:}

As recommended by the reviewer, we no longer refer to the difference between the two ears as functional recovery, calculated in percentage (see the next po int).

\section{Comments to the Authors}

5. How was PERCENT RECOVERY calculated?? I had asked for a clarification of how $\%$ recovery was calculated, and this was not provided. The authors state that "The percentage of recovery was calculated as the difference in PTS at day 30 between the treated and nontreated cochlea." A difference in PTS would be expressed in $\mathrm{dB}$, not \%, so this does not explain how percent recovery was calculated. How was a dB difference converted to percent recovery??

\section{Authors answer:}

In the submitted version, we expressed the differences between the two ears (previously named recovery) in percentage. Generally, presentation as percentage allows a normalization of the data. Since we do not need such normalization, we have followed the reviewer's advice. We now describe the results in terms of hearing loss in the text and we present the dose- (fig. 1B) and the time-efficacy (Fig. $4 \mathrm{~A}$ ) in terms of hearing loss calculated in $\mathrm{dB}$ as a function of the pre-exposure threshold from the same ear. This is mentioned in the legends of figs 1 and 4.

See page 42, line 11 .

"Dose-dependent effects of BN 8227030 days after sound trauma. Hearing loss at $10 \mathrm{kHz}$ was calculated as the difference in hearing thresholds measured before and 30 days after sound exposure, within the same perfused ear."

And page 45, line 21.

"Hearing loss at $10 \mathrm{kHz}$ was calculated as the difference in hearing thresholds measured before and 30 days after sound exposure, within the same perfused ear."

Min or concerns:

\section{Comments to the Authors}

1. p. 12, line 10: are the numbers for variability SD or SEM?

\section{Authors answer:}


There are means \pm SEM (see page 13, line 5).

\title{
Comments to the Authors
}

2. p. 12, line 21: The authors state that "In the next few days, PTS in the perfused ears was significantly lower..." This should be TTS? When does TTS become PTS? How were the differences tested for significance and what were the statistical results?

\begin{abstract}
Authors answer:
We answer the question in the result session (line 22, page 13):

"Two days after sound exposure, threshold shift in the perfused ears was significantly lower than in the control contralateral ears. In addition, no subsequent deterioration in thresholds was observed in the perfused ears over the next 28 days".
\end{abstract}

\section{Comments to the Authors}

3. The authors stated previously that "This led to fewer cases of perman ent hearing loss." The issue of "number of animals showing less hearing loss" (an issue that can be addressed with Chi-square analysis) versus a change in mean hearing loss has not been addressed in the response, nor has the statement been changed in the text.

\section{Authors answer:}

The issue of "number of animals showing less hearing loss" versus a change in mean hearing loss has not been statistically addressed because improvement of thresholds occurred in all animal

This is now specified in the discussion (line 16, page 19):

"Although it did not reduced temporary threshold shift, BN 82270 perfusion improved recovery of thresholds with almost no PTS at $48 \mathrm{~h}$ after sound trauma"

\section{Comments to the Authors}

4. Scale bars have been left off of figures in Fig. 1.

Au thors answer:

Scale bars have been added to Fig. 1 .

5. p. 5, still refers to "sensory cell loss."

Au thors answer:

"sensory cell loss." has been changed to "hair cell loss".

\section{Comments to the Authors}

Grammar and Typos:

1. p. 12, line 10: change controlateral to contralateral

2. p. 6 , line 10: change in traperitoneale to I.P.

3. p. 6, indicate what AP is artificial perilymph

4. p. 7, RWM delivery: sentence states that the minipump was placed on the round window membrane.

5. p. 10 and elsewhere, place comma after "i.e."

6. p. 10, it may be better to refer to "middle" turns rather than "medial" turns

7. p. 21 , "better cell penetration" -better than what?

8. p. 22., top paragraph as 2 in complete sentences

9. p. 41, cochleae should be cochlea

Authors answer:

All these typos and grammar have been corrected accordingly. 